\title{
Dynamics of dissolved and biogenic silica in the freshwater reaches of a macrotidal estuary (The Scheldt, Belgium)
}

\author{
Vincent Carbonnel · Marie Lionard • \\ Koenraad Muylaert · Lei Chou
}

Received: 22 December 2008/ Accepted: 1 July 2009/Published online: 31 July 2009

(C) Springer Science+Business Media B.V. 2009

\begin{abstract}
Temporal evolution of dissolved and biogenic silica concentrations along the Scheldt tidal river and in its tributaries was investigated during 1 year in 2003. In the tributaries, dissolved silica (DSi) concentrations remained high and biogenic silica (BSi) concentrations were low throughout the year. In the tidal river during summer, DSi was completely consumed and BSi concentrations increased. Overall, most of the BSi was associated with living diatoms during the productive period in the tidal river.
\end{abstract}

V. Carbonnel $(\bowtie) \cdot$ L. Chou $(\square)$

Laboratoire d'Océanographie Chimique et Géochimie des Eaux, Faculté des Sciences, Université Libre de Bruxelles, Campus de la Plaine, CP 208, Boulevard du Triomphe, 1050 Brussels, Belgium

e-mail: Vincent.Carbonnel@ulb.ac.be

L. Chou

e-mail: Lei.Chou@ulb.ac.be

M. Lionard · K. Muylaert

Protistology and Aquatic Ecology, Biology Department, Ghent University, Krijgslaan 281-S8, 9000 Ghent,

Belgium

Present Address:

M. Lionard

Institut des Sciences de la Mer de Rimouski, Université du Québec à Rimouski, 310 Allée des Ursulines,

CP 3300 Rimouski, QC G5L 3A1, Canada

Present Address:

K. Muylaert

K.U. Leuven, Campus Kortrijk, Biology Department,

E. Sabbelaan 53, 8500 Kortrijk, Belgium
Nevertheless, the detrital $\mathrm{BSi}$ was a significant fraction of the total $\mathrm{BSi}$ pool, of which less than $10 \%$ could be attributed to phytoliths. The tidal river was divided into two zones for budgeting purposes. The highest productivity was observed in the zone that received the highest water discharge, as higher riverine DSi input fluxes induced presumably a less restrictive DSi limitation, but the discharge pattern could not explain all by itself the variations in DSi consumption. Silica uptake and retention in the tidal river were important at the seasonal time-scale: from May to September, $48 \%$ of the riverine DSi was consumed and $65 \%$ of the produced BSi was deposited, leading to a silica ( $\mathrm{DSi}+\mathrm{BSi}$ ) retention in the tidal river of $30 \%$. However, when annual fluxes were considered, DSi uptake in the tidal river amounted to $14 \%$ of the DSi inputs and only $6 \%$ of the riverine silica $(\mathrm{DSi}+\mathrm{BSi})$ was retained in the tidal river.

Keywords Biogenic silica - Diatoms ·

Dissolved silica $\cdot$ Scheldt estuary .

Silica budget . Tidal freshwater

$\begin{array}{ll}\text { Abbreviations } \\ \mathrm{BSi} & \text { Biogenic silica } \\ \mathrm{BSi}_{\mathrm{det}} & \mathrm{BSi} \text { not associated with living diatoms } \\ \mathrm{BSi}_{\text {liv }} & \mathrm{BSi} \text { associated with living diatom } \\ \mathrm{DiatChl} a & \text { Chlorophyll } a \text { ascribed to diatoms } \\ \mathrm{DSi} & \text { Dissolved silica } \\ \mathrm{POC} & \text { Particulate organic carbon }\end{array}$


$\mathrm{POC}_{\text {nld }} \quad$ POC not corresponding to living diatoms

SPM Suspended particulate matter

$\mathrm{SPM}_{\text {nbld }} \quad \mathrm{SPM}$ not corresponding to BSi nor to living diatoms

\section{Introduction}

Dissolved silica (DSi) is a key nutrient for the aquatic ecosystem as diatoms have an essential requirement for DSi to build up their frustules, rigid outer cell walls made of amorphous biogenic silica (BSi) (Ragueneau et al. 2000). Diatoms often dominate the primary production in turbid aquatic environments such as rivers, estuaries and coastal zones (Ragueneau et al. 2000), and account for $75 \%$ of the primary production in the world's coastal areas (Nelson et al. 1995). They can support an efficient aquatic food chain (Turner et al. 1998) and may play a significant role in the export of carbon from surface waters (Tréguer and Pondaven 2000; Ploug et al. 2008). The availability of DSi and its relative abundance compared to the other nutrients can influence the composition of the phytoplankton community, which can subsequently affect the ecological functioning of the ecosystem (Officer and Ryther 1980; Conley et al. 1993; Lancelot 1995; Turner et al. 1998). However, riverine DSi fluxes, which are the main source of DSi to the oceans (Wollast 1974; Tréguer et al. 1995), have been altered by human activities during the last decades. Land-use activities, such as deforestation, may affect the DSi inputs to rivers (Conley et al. 2008) and the use of silica in washing powders (Verbanck et al. 1994) and fertilizers (Datnoff et al. 2001) may also constitute an additional DSi source to rivers. In contrast, eutrophication results in enhanced silica retention in lakes, rivers and estuaries (Conley et al. 1993). Decreased silica concentrations are also induced by river damming and river regulation, which cause particle trapping and reduce contact between the water and the riparian vegetated zone containing DSi-rich interstitial waters (Humborg et al. 2006).

Most of the DSi is originally produced during rock weathering on land where it generally goes through a terrestrial cycle before reaching the rivers (Derry

et al. 2005). On its way to the coastal zone, DSi participates in aquatic biogeochemical cycles in rivers and estuaries (Conley et al. 1993), involving a number of biological, chemical and physical processes. Diatom blooms occurring in spring/summer in rivers and estuaries result in significant decreases in DSi and concomitant increases in BSi concentrations, which can account for $50-70 \%$ of the total riverine silica load (Admiraal et al. 1990; Conley 1997). As particulate material, BSi can settle and accumulate in the sediments, inducing retention of silica in the ecosystem. It can also be transported downstream as suspended material (Admiraal et al. 1990) and/or be dissolved at biological timescales (Roubeix et al. 2008; Loucaides et al. 2008). BSi dissolution is however not expected to occur at the same rate along the salinity gradient: BSi dissolution rate increases with salinity (Loucaides et al. 2008) and the bacterial community can significantly enhance the remineralisation (Bidle and Azam 1999; Roubeix et al. 2008). In addition, phytoliths (BSi material produced by terrestrial higher plants) can add a significant, if not major, contribution to the BSi pool carried by rivers (Cary et al. 2005). They can originate from top soil erosion (Cary et al. 2005) as well as directly from the vegetation of the river banks or tidal marshes (Struyf et al. 2006). Marshes can retain significant amounts of silica in the aboveground biomass and in sediments (Struyf et al. 2005) and DSi and BSi exchange between the river channel and the marshes can affect the estuarine silica cycle (Struyf et al. 2006). Thus, because of the possibly important riverine and estuarine BSi concentrations, its specific behaviour and its interaction with DSi, the study of BSi dynamics should not be omitted when silica fluxes and mass-balances in rivers and estuaries are assessed.

In some estuaries, the tidal influence propagates further inland than salt intrusion, leading to the existence of tidal freshwater reaches which may host important chemical and biological processes (McLusky 1993; Schuchardt et al. 1993; Muylaert et al. 2005). In particular, tidal freshwater reaches exhibit specific features which can influence the phytoplankton dynamics (Schuchardt et al. 1993; Lionard 2006) and thus the biogeochemical cycle of nutrients. They differ from the adjacent rivers by longer water residence times and the presence of tides, which induces higher turbulence and turbidity (Schuchardt 
et al. 1993; McLusky 1993). The resulting low light conditions may limit phytoplankton growth but may also favour diatoms due to their lower light requirements compared to other algae (Reynolds 1988; Cushing 1989; Lionard 2006). In contrast to the downstream areas where freshwater and seawater mix, there is no phytoplankton mortality due to salinity stress in tidal freshwater reaches (Schuchardt et al. 1993; Muylaert et al. 2000). Thus, if the residence time is sufficiently long, a maximum in the diatom production and the associated DSi consumption may occur in the tidal freshwater reaches (Anderson 1986; Schuchardt and Schirmer 1991; De Sève 1993; Schuchardt et al. 1993; Muylaert et al. 2005).

In the present study, we focus on the Scheldt estuary which comprises an extensive tidal freshwater area. The biogeochemistry of silica and the fluxes of this nutrient in the continuum of the Scheldt are of primary importance as they can affect the ecosystem in the adjacent coastal zone. Earlier works have shown that DSi drives the extent of the early spring diatom bloom in this zone, while the excess of dissolved inorganic nitrogen stimulates a subsequent massive development of flagellates (Phaeocystis sp.) which alters both the food web and the environment (Lancelot 1995). The highest (diatom-dominated) phytoplankton biomass and production of the Scheldt estuary were observed in the tidal freshwater reaches, resulting in strong seasonal patterns in DSi concentrations, possibly consumed down to limiting levels in summer (Muylaert et al. 2001, 2005; Struyf et al. 2004; Van Damme et al. 2005; Soetaert et al. 2006). The long-term evolution of DSi concentrations as well as the variation of DSi concentrations with increasing discharge have been investigated (Muylaert et al. 2001; Struyf et al. 2004; Soetaert et al. 2006). But until now, BSi dynamics have not been studied and little is known about the silica biogeochemical cycle in the Scheldt tidal freshwater reaches. Low summer DSi concentrations and high diatom-dominated phytoplankton biomass (Muylaert et al. 2000; Van Damme et al. 2005; Lionard 2006) suggest however that BSi can be a major constituent of the silica pool in this environment. DSi and BSi dynamics were investigated by Arndt et al. (2007) and Arndt and Regnier (2007) using model simulations of diatom dynamics calibrated on DSi concentrations, but observations on measured BSi dynamics should still be performed and compared to the model results. Being a part of the suspended particulate matter (SPM), BSi in the Scheldt tidal freshwater reaches is expected to follow a complex behaviour due to spatial and temporal variability in SPM dynamics (Chen et al. 2005a). Due to diatom mortality, resuspension of dead diatom frustules and the possible presence of phytoliths, a significant fraction of the BSi may not be associated with living diatoms. In addition, marshes along the Scheldt tidal freshwater reaches may act as DSi recyclers or sinks for estuarine $\mathrm{BSi}$, and may play a role in the estuarine silica cycle (Struyf et al. 2006, 2007b). As they also contain significant amounts of phytolith in the aboveground biomass (Struyf et al. 2005), BSi as phytoliths may be provided to the estuarine waters by tidal exchange of this biogenic material between the river channel and marshes.

In this study, we present high resolution DSi and BSi temporal profiles during one full annual cycle along the tidal freshwater reaches of the Scheldt and its tributaries. BSi concentrations are compared with those of chlorophyll $a$ and SPM to estimate the fraction of $\mathrm{BSi}$ associated with living diatoms. A budget is performed for $\mathrm{DSi}$ and the different $\mathrm{BSi}$ fractions (associated or not with living diatoms) for the period from May to October 2003 and annual fluxes to the brackish reaches of the Scheldt estuary are estimated. The possible contribution of phytoliths to the estuarine BSi pool as well as the influence of the silica cycling in marshes on the estimated silica fluxes are discussed.

\section{Materials and methods}

Description of the study area

The $355 \mathrm{~km}$ long Scheldt river and estuary takes its source in Northern France. It flows through Belgium where it receives waters mainly from the Leie (confluence at Ghent), the Dender and the Rupel, and discharges into the North Sea via the Netherlands (Fig. 1). The shallow, well-mixed and turbid macrotidal estuary of the Scheldt has been extensively described (e.g. Chen et al. 2005a; Meire et al. 2005; Van Damme et al. 2005; Soetaert et al. 2006). The tidal freshwater part of this system (called hereafter the "tidal river") stretches from near Hemiksem (km 
Fig. 1 Map of the Scheldt estuary. City and river names are in regular and italic fonts, respectively. The sampling stations (in bold) are indicated by black dots. On the Dender, Zenne, Dijle, Grote Nete, Kleine Nete and at Ghent, they correspond to the tidal limits of the estuary. The Durme is nowadays a dead arm with negligible discharge. The dashed line follows the border between Belgium and the Netherlands. The areas (Zones 1a and $1 \mathrm{~b}$, and Zone 2) considered for silica budget calculations are delimited by grey lines

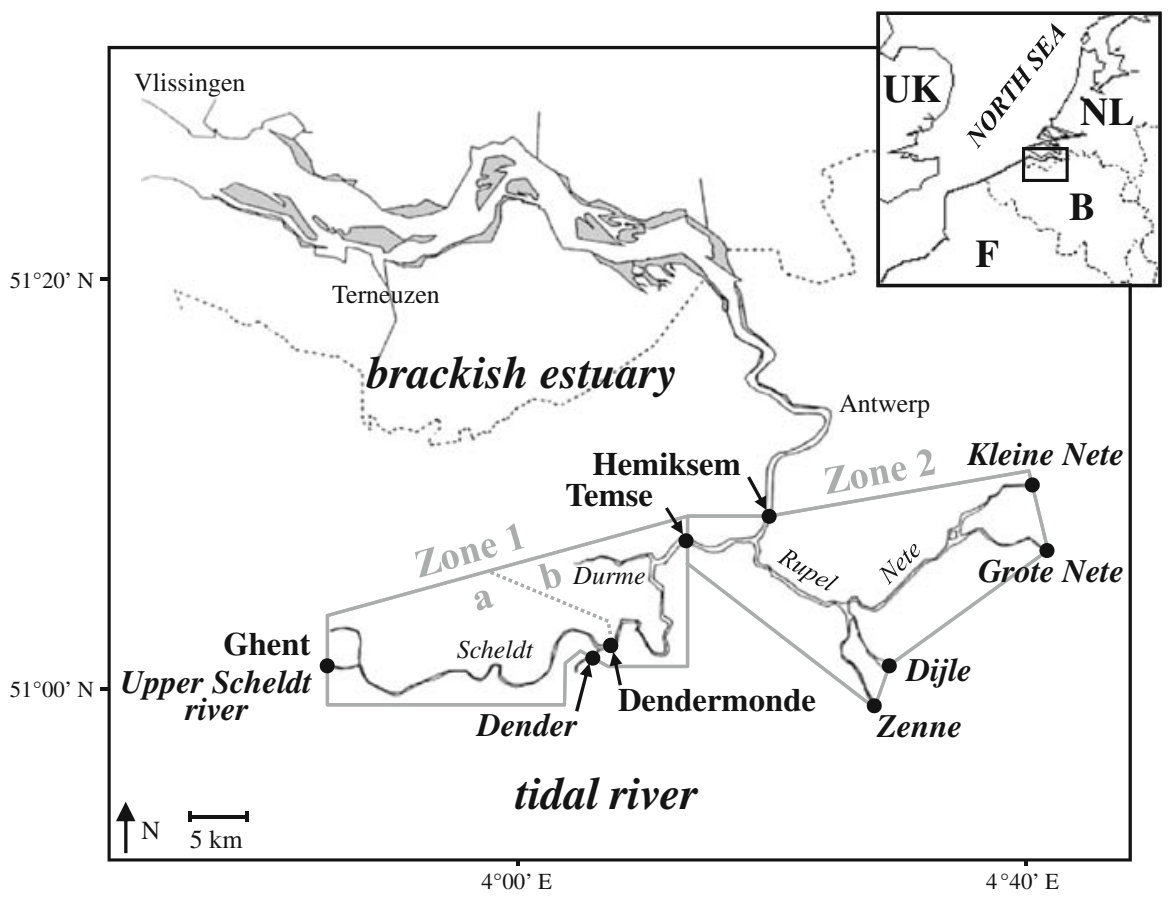

91, i.e. $91 \mathrm{~km}$ from the mouth of the estuary at Vlissingen) to Ghent ( $\mathrm{km} \mathrm{157)}$. The tidal wave is blocked by sluices at Ghent and at the mouth of the river Dender. The tidal river system also includes the river Rupel (confluence with the Scheldt at km 94) and the downstream parts of its four tributaries where the tidal influence decreases naturally (Fig. 1). The tidal river consists of a single ebb/flood channel bordered by mudflats and marshes, which account for $28 \%$ of the total surface of the tidal river system (Meire et al. 2005). The channel is however almost completely canalised upstream of Dendermonde (Meire et al. 2005).

The Scheldt is a rain fed river exhibiting strong seasonal and inter-annual variations in water discharge (Fig. 2; Soetaert et al. 2006). Before it enters the Scheldt estuary, the water from the river Scheldt may be partially or even completely deviated towards the Ghent-Terneuzen canal to sustain industrial and navigation needs. The contribution of the Rupel to the total freshwater input can therefore increase from about $46 \%$ in winter to more than $70 \%$ during dry summers. The increase in freshwater residence time during the summer period is thus more pronounced in the Scheldt between Ghent, Dendermonde and Temse than in the Rupel and in the Nete (Table 1).
After decades of heavy pollution history, the Scheldt estuary is still strongly affected by human activities, and nitrogen and phosphorous concentrations are never limiting factors for phytoplankton growth (Van Damme et al. 2005; Soetaert et al. 2006; Van der Zee et al. 2007). In 2003, maximum dissolved inorganic nitrogen and phosphorous concentrations reached 1,300 and $50 \mu \mathrm{mol} \mathrm{L}{ }^{-1}$, respectively (Van der Zee et al. 2007). In contrast, silica can be depleted in summer in case of low water discharge (Muylaert et al. 2001).

The phytoplankton community in the tidal river is dominated by diatoms throughout the year (Muylaert et al. 2000; Lionard 2006; Lionard et al. 2008a). Two blooms have been identified: one in spring, originating from the upper Scheldt river and dominated by Stephanodiscus hanszchii; another one in summer, which develops in situ near Dendermonde and is dominated by Cyclotella scaldensis, a genus closely related to C. meneghiniana (Muylaert et al. 2000).

\section{Sampling stations}

The Scheldt tidal river and its tributaries were sampled once a week from February 2003 to February 2004, except in winter (once a month). 


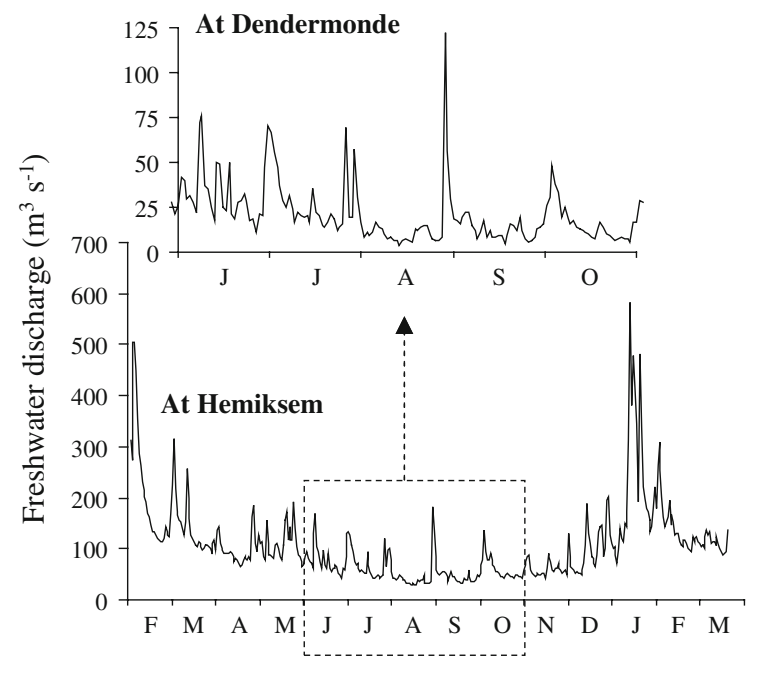

Fig. 2 Daily average of the residual freshwater discharge at Hemiksem (from February 2003 to March 2004) and at Dendermonde (from June to October 2003)

The sampling was performed from a bridge or a landing stage. The upper Scheldt river and the five main tributaries (the Dender, Zenne, Dijle, Kleine and Grote Nete) were sampled at the tidal limits (Fig. 1). The tidal river was sampled at three stations: Dendermonde ( $\mathrm{km} \mathrm{124),} \mathrm{Temse}(\mathrm{km} \mathrm{101)}$ and Hemiksem (km 91). Hemiksem was considered as the downstream limit of the tidal river, as the salinity at this station was on average 1 and never exceed 2.9. Two zones, delimited by the sampling stations, were defined for the budget calculations (Fig. 1). The two zones have approximately the same volume (about $3 \times$ $10^{7} \mathrm{~m}^{3}$ at mid tide) and water surface area (about $7 \times 10^{6} \mathrm{~m}^{2}$ ) but differ in total length (Table 1).

Chemical analyses

\section{$S P M, D S i$ and $B S i$}

Water samples (from 20 to $150 \mathrm{~mL}$ ) were vacuum filtered on a pre-weighed polycarbonate filter (Whatman Nuclepore, $\varnothing 47 \mathrm{~mm}, 0.4 \mu \mathrm{m}$ pore size). The filtrate was acidified (with $200 \mu \mathrm{L}$ of $2 \mathrm{~mol} \mathrm{~L}^{-1} \mathrm{HCl}$ per $50 \mathrm{~mL}$ of sample) and kept in the dark at $4^{\circ} \mathrm{C}$ until it was measured colorimetrically for DSi on a Skalar Auto-analyser following a method adapted from Koroleff (1983). The SPM collected on the filter was rinsed with Milli-Q water and dried overnight at $50^{\circ} \mathrm{C}$. The filter was weighed again for the SPM determination by weight difference and the filter was kept for BSi analysis.

BSi was determined by a wet-alkaline method. Because high amounts of lithogenic silica are present in the SPM of the tidal river (Bouezmarni and Wollast 2005), the aluminium released during the digestions was used to correct for the concomitant dissolution of $\mathrm{Si}$ from lithogenic material. The methods from Kamatani and Oku (2000) and Ragueneau et al. (2005) were combined and modified. The digestion was performed on a single SPM filter and,

Table 1 Characterization of the Scheldt tidal river

\begin{tabular}{|c|c|c|c|c|c|c|}
\hline \multirow{2}{*}{$\begin{array}{l}\text { River } \\
\text { section }\end{array}$} & \multicolumn{3}{|l|}{ Average } & \multicolumn{2}{|c|}{ Residence time (day) } & \\
\hline & Depth (m) & Length (m) & Width (m) & Summer & Winter & \\
\hline \multicolumn{7}{|l|}{ Scheldt } \\
\hline from Ghent to Dendermonde & 3.2 & 38 & 68 & $4.0 \pm 1.7$ & $1.3 \pm 0.9$ & Zone 1a \\
\hline from Dendermonde to Temse & 4.5 & 25 & 190 & $7.4 \pm 2.8$ & $2.3 \pm 1.5$ & Zone $1 \mathrm{~b}$ \\
\hline from Temse to Rupel mouth & 4.8 & 6 & 394 & $3.8 \pm 1.4$ & $1.2 \pm 0.8$ & \multirow{6}{*}{ Zone 2} \\
\hline from Rupel mouth to Hemiksem & 6.9 & 3 & 363 & $1.2 \pm 0.3$ & $0.5 \pm 0.2$ & \\
\hline Rupel (entire) & 4.2 & 11 & 180 & $2.3 \pm 0.5$ & $1.1 \pm 0.4$ & \\
\hline Nete (entire) & 2.8 & 16 & 49 & $1.9 \pm 0.6$ & $0.8 \pm 0.3$ & \\
\hline Zenne (last $10 \mathrm{~km}$ ) & 1.6 & (10) & 32 & $0.6 \pm 0.1$ & $0.4 \pm 0.1$ & \\
\hline Dijle (last $8 \mathrm{~km}$ ) & 2.5 & $(8)$ & 35 & $0.4 \pm 0.1$ & $0.2 \pm 0.1$ & \\
\hline
\end{tabular}

Average depths and widths were calculated from the volumes and water surface areas of the considered sections. Lengths, volumes and water surface areas were estimated from WLHO (1966). No separate bathymetric data were available for the Grote and Kleine Nete. Residence times of water (with standard deviations) correspond to the period 1996-2005. They were computed as the quotient of the volume of the considered section by the average water discharge. The zones (rightmost column) correspond to those in Fig. 1 
compared to Ragueneau et al. (2005), four digestion steps were performed (instead of two) to improve the correction (Fig. 3). Furthermore, the SPM was not rinsed between the steps to reduce the time necessary for the digestion.

The filter with the SPM was placed at the bottom of a $15 \mathrm{~mL}$ polypropylene centrifugation tube and covered with $10 \mathrm{~mL}\left(V_{D}\right)$ of $0.2 \mathrm{~mol} \mathrm{~L}^{-1} \mathrm{NaOH}$ (Fig. 3). The tube was incubated in a shaking water bath at $95^{\circ} \mathrm{C}$ for $1 \mathrm{~h}$ (step 1), and centrifuged at
$c_{n}=\left(\frac{V_{D}-V_{A}}{V_{D}}\right)^{n-1}$

where $B S i$ is the amount of $\mathrm{BSi}$ on the filter, $V_{D}$ and $V_{A}$ the volumes of $0.2 \mathrm{~mol} \mathrm{~L}^{-1} \mathrm{NaOH}$ additions (respectively 10 and $5 \mathrm{~mL}$, Fig. 3) and $d$ the dilution factor of 1.25 due to the addition of $\mathrm{HCl}$ in the aliquots of the supernatant solutions. $B S i$ (as well as $k$, not shown) is then calculated by a least-squares multiple regression on $S i_{n}$ :

$B S i=V_{D} \cdot d \cdot \frac{\left(\sum_{n=1}^{4} A l_{n}^{2}\right) \cdot\left(\sum_{n=1}^{4} c_{n} \cdot S i_{n}\right)-\left(\sum_{n=1}^{4} c_{n} \cdot A l_{n}\right) \cdot\left(\sum_{n=1}^{4} S i_{n} \cdot A l_{n}\right)}{\left(\sum_{n=1}^{4} c_{n}^{2}\right) \cdot\left(\sum_{n=1}^{4} A l_{n}^{2}\right)-\left(\sum_{n=1}^{4} c_{n} \cdot A l_{n}\right)^{2}}$

5,000 rpm, $5^{\circ} \mathrm{C}$ during $10 \mathrm{~min}$. A $5 \mathrm{~mL}\left(V_{A}\right)$ aliquot of the supernatant was taken and acidified with $1.25 \mathrm{~mL}$ of $1 \mathrm{~mol} \mathrm{~L}^{-1} \mathrm{HCl}$. This digestion step was then repeated three times (steps 2-4): $5 \mathrm{~mL}$ of $0.2 \mathrm{~mol} \mathrm{~L}^{-1} \mathrm{NaOH}$ was added to the remaining solution in the centrifugation tube, and the tube was placed again in the shaking water bath but for $30 \mathrm{~min}$.

The four aliquots of the supernatant solutions were analysed for DSi and $\mathrm{Al}$ concentrations $\left(S i_{n}\right.$ and $A l_{n}$, with $n=1-4$ ), either by ICP-OES (Inductively Coupled Plasma-Optic Emission Spectroscopy) or by colorimetry: using a Skalar Auto-analyser for DSi (as described previously) and manually for dissolved Al following Dougan and Wilson (1974). There were no significant differences between the results obtained by the two methods for DSi analyses. Following Kamatani and Oku (2000) and Ragueneau et al. (2005), we assumed that: (1) all the BSi is dissolved during the first digestion step, (2) all the $\mathrm{Al}$ measured originates from the digestion of lithogenic material and (3) this lithogenic material dissolves with a constant $\mathrm{Si} / \mathrm{Al}$ ratio (designated here $k$ ). Under these assumptions, the DSi and Al concentrations measured in the aliquots follow the equation:

$S i_{n}=c_{n} \cdot \frac{B S i}{V_{D} \cdot d}+k \cdot A l_{n}$

with
Among the 260 correlation coefficients $r^{2}$ obtained from the multiple regressions performed for each $\mathrm{BSi}$ measurement presented in this study, $71 \%$ were higher than 0.999 and $95 \%$ higher than 0.995 . In addition, the method was tested on pure lithogenic and biogenic silica suspensions, and known mixtures of the two (data not shown). This supports the three assumptions indicated above and validates the use of Eq. 1.

In the following, BSi concentrations are expressed

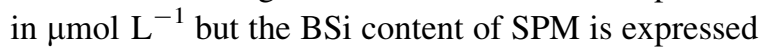
as the mass content of hydrated silica $\mathrm{SiO}_{2} \cdot m \mathrm{H}_{2} \mathrm{O}$, with $m \leq 2$ (Martin-Jézéquel et al. 2000); we assumed $m=1 / 3$, a value close to the measurement of Kamatani and Oku (2000).

\section{Particulate organic carbon and contribution of diatoms to the chlorophyll a concentrations}

SPM was collected on a precombusted $\left(4 \mathrm{~h}, 500^{\circ} \mathrm{C}\right)$ GF/F filter $(\varnothing 47 \mathrm{~mm}, 0.7 \mu \mathrm{m}$ pore size) for the determination of particulate organic carbon (POC), and on a GF/F filter $(\varnothing 25 \mathrm{~mm}, 0.7 \mu \mathrm{m}$ porosity) for the measurement of chlorophyll $a$ and marker pigments. Both filters were kept frozen at $-20^{\circ} \mathrm{C}$ until analysis. POC was measured using a Fisons NA1500 elemental analyser after carbonate removal from the filters by overnight exposure to strong acid fumes. Pigments concentrations were measured by 
Fig. 3 Scheme of the BSi digestion protocol

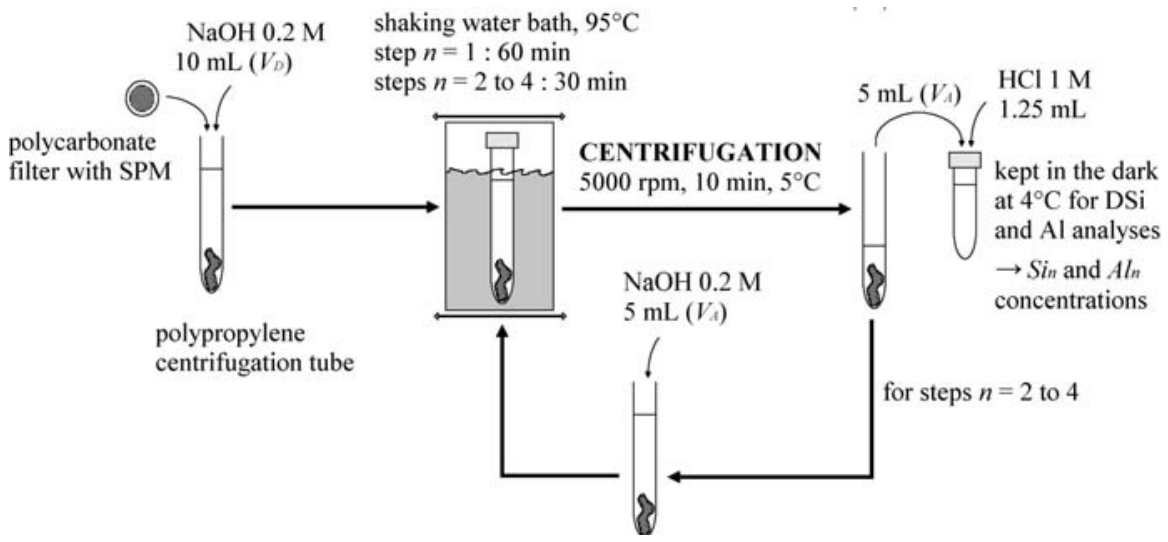

- DiatChla and SPM expressed in $\mathrm{mg} \mathrm{L}^{-1}$, and BSi in $\mathrm{mmol} \mathrm{L}^{-1}$,

- the molar mass of $\mathrm{BSi}$ (as hydrated $\mathrm{SiO}_{2}$ ): $\mathrm{M}_{\mathrm{BSiO}_{2}}=66 \mathrm{~g} \mathrm{~mol}^{-1}$,

- the chlorophyll $a$ to POC mass ratio in the (diatom-dominated) phytoplankton of the Scheldt tidal river: $\beta_{\mathrm{POC} / \mathrm{Chl} a}=30$ (Muylaert et al. 2001),

- the conversion factor from POC to organic matter: $\beta_{\mathrm{OM} / \mathrm{POC}}=2.5$. This value corresponds to the ratio of the molar masses of $\mathrm{CH}_{2} \mathrm{O}$ and $\mathrm{C}$, and was also observed in an eutrophic estuary by Suzumura et al. (2004).

The distinction between $\mathrm{BSi}_{\mathrm{liv}}$ and $\mathrm{BSi}_{\text {det }}$ was made by performing a multiple regression between $\mathrm{BSi}$ and the two explicative variables DiatChla and $\mathrm{SPM}_{\text {nbld }}$ : the partial coefficients associated with DiatChl $a$ and $\mathrm{SPM}_{\text {nbld }}$ (respectively $k_{1}$ and $k_{2}$ ) were fitted to obtain the best correlation between measured BSi concentrations and those estimated by the

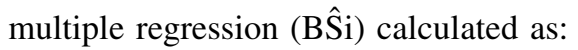

$\mathrm{BSi}=k_{1} \cdot$ DiatChl $a+k_{2} \cdot \mathrm{SPM}_{\mathrm{nbld}}$

$\mathrm{BSi}_{\text {liv }}$ was estimated as the product of $k_{1}$ (called hereafter $\mathrm{BSi}_{\mathrm{liv}} /$ DiatChl $a$ ) and DiatChl $a$, and $\mathrm{BSi}_{\mathrm{det}}$ was calculated as the difference between $\mathrm{BSi}$ and $\mathrm{BSi}_{\text {liv }}$. The multiple regressions (as well as correlations and statistical Student's $t$-tests) were performed following Dagnelie (1973, 2006) but without any independent constant terms, as the latter would not have been significantly different from zero (at $95 \%$ confidence) if they were appended.

with 
Discharge data, silica fluxes and mass-balances calculations

Daily discharge data for the upper Scheldt river and the five main tributaries as well as an estimation of the overall lateral inputs for Zone 1 and Zone 2 were provided by the Flemish Administration (Afdeling Maritieme Toegang). The lateral inputs (non-monitored lateral sources of water discharging directly into the tidal river, such as run-off or small lateral streams) accounted for less than $10 \%$ of the annual discharge in 2003; they were redistributed among the tributaries of the zone, according to their contribution to the total riverine water input. Discharges at Dendermonde, Temse and Hemiksem were calculated as the sum of the discharges of the upstream tributaries. However, as Dendermonde is situated roughly half-way between Ghent and Temse, half of the contribution of the lateral inputs in Zone 1 was transferred from Zone 1a to Zone 1b in the water (and the silica) mass-balance (Fig. 1).

Silica fluxes $\left(\mathrm{kmol} \mathrm{day}^{-1}\right)$ were calculated at a weekly resolution: daily discharge data were weekly averaged and multiplied by the weekly measured silica concentration. If no sampling was carried out during a week, the concentration was estimated by linear interpolation between the two closest measurements. In the tributaries of the Rupel, BSi was not measured every week, but weekly BSi fluxes were calculated with BSi concentrations derived from the weekly DiatChl $a$ concentrations and the slopes and intercepts of the linear regressions performed between measured BSi and corresponding DiatChl $a$ concentrations in each river. The intercepts of the linear regressions were assumed to provide estimations for the detrital BSi fractions. For the Zenne, as the dataset did not allow such linear regression, the slope and the intercept used were the averages of those found for the Dijle, Grote and Kleine Nete.

Mass-balances were performed for $\mathrm{DSi}, \mathrm{BSi}_{\text {liv }}$ and $\mathrm{BSi}_{\text {det }}$ in Zones $1 \mathrm{a}, 1 \mathrm{~b}$ and 2 during the productive period. In each zone, the loss of DSi was ascribed to DSi uptake by diatom and thus to a production of $\mathrm{BSi}_{\text {liv }}$. The mass-balance between this production and the fluxes of $\mathrm{BSi}_{\text {liv }}$ was assumed to provide an estimate of the diatom mortality. The mass-balance between diatom mortality and fluxes of $\mathrm{BSi}_{\text {det }}$ was considered as representative of the BSi deposition (or resuspension) in each zone.

\section{Results}

Distribution of DSi, BSi and DiatChla at the tidal limits of the Scheldt and its tributaries

In general, diatoms accounted for less than half of the phytoplankton biomass in the six rivers (Table 2) and the DiatChla concentrations were below $50 \mu \mathrm{g} \mathrm{L}^{-1}$ (Fig. 4a-f). DSi concentrations remained high throughout the year with mean annual concentrations ranging from $154 \mu \mathrm{mol} \mathrm{L}{ }^{-1}$ in the Kleine Nete to $288 \mu \mathrm{mol} \mathrm{L}^{-1}$ in the Dijle. BSi concentrations were lower with mean annual concentrations varying from $2.9 \mu \mathrm{mol} \mathrm{L}{ }^{-1}$ in the Dijle to $18.2 \mu \mathrm{mol} \mathrm{L}^{-1}$ in the upper Scheldt river. Both the DiatChla and the BSi concentrations were higher in the river Scheldt (at Ghent) and in the Dender (Fig. 4a, b) than in the tributaries of the Rupel (Fig. 4c-f). Few BSi data were available for the Zenne, as mostly negative values were retrieved from Eq. 3 (data not shown, see "Discussion"). At the end of March and the beginning of April in the upper Scheldt river, higher DiatChl $a$ concentrations indicated a spring diatom bloom (Fig. 4a). However only a small increase in BSi concentrations could be observed. Other smaller concomitant increases in $\mathrm{BSi}$ and DiatChla patterns were observed in spring in all rivers and in summer in the upper Scheldt, the Dender and the Dijle (Fig. 4a-f). DSi concentrations also decreased during both seasons in the upper Scheldt and the Dender.

Table 2 Average contributions of the diatoms to the phytoplankton biomass at the nine sampling stations (in percentages)

\begin{tabular}{llll}
\hline Station & $\begin{array}{l}\text { Spring } \\
\text { (March-May) }\end{array}$ & $\begin{array}{l}\text { Summer } \\
\text { (June- } \\
\text { September) }\end{array}$ & $\begin{array}{l}\text { Autumn-Winter } \\
\text { (October- } \\
\text { February) }\end{array}$ \\
\hline Ghent & $\mathbf{6 0}$ & 40 & 39 \\
Dender & 30 & 23 & 30 \\
Zenne & 29 & 16 & 20 \\
Dijle & 36 & 24 & 23 \\
Grote Nete & 33 & 17 & 32 \\
Kleine Nete & 26 & 15 & 17 \\
Dendermonde & $\mathbf{7 8}$ & $\mathbf{8 5}$ & $\mathbf{7 1}$ \\
Temse & $\mathbf{7 2}$ & $\mathbf{6 9}$ & $\mathbf{6 0}$ \\
Hemiksem & 46 & $\mathbf{5 6}$ & 31 \\
\hline
\end{tabular}

Contributions over $50 \%$ are indicated in bold 
Distribution of DSi, BSi and DiatChla

along the tidal river

Diatoms accounted for more than $60-70 \%$ of the phytoplankton biomass throughout the year 2003 at Dendermonde and Temse (Table 2). Although the fraction of the phytoplankton biomass attributed to diatoms was significantly lower at Hemiksem (Table 2), diatoms were still the dominant phytoplankton species (Lionard 2006).

A spring bloom could be observed at Dendermonde at the end of March and the beginning of April (Fig. $4 \mathrm{~g}$ ) but was not noticeable at Temse and Hemiksem (Fig. 4h, i). Until the end of May, DSi concentrations remained high ranging from 150 to $250 \mu \mathrm{mol} \mathrm{L}^{-1}$ at the three stations and BSi stayed low at around 36, 20 and $13 \mu \mathrm{mol} \mathrm{L} \mathrm{L}^{-1}$, respectively at Dendermonde, Temse and Hemiksem.

In summer, DiatChl $a$ and $\mathrm{BSi}$ concentrations increased concomitantly while DSi decreased (Fig. 4g-i), indicating the development of a summer diatom bloom (June to September) in the tidal river. At Dendermonde (Fig. 4g), DSi was consumed by diatoms down to $2 \mu \mathrm{mol} \mathrm{L}{ }^{-1}$ and was entirely transformed into BSi from the beginning of July to the end of September. The BSi concentrations fluctuated at around $200 \mu \mathrm{mol} \mathrm{L}^{-1}$ and correlated well with the DiatChla concentrations (except on 11 and 25 August 2003 when DiatChl $a$ declined while BSi remained high). Increases in DSi observed at the beginning of July and September occurred a few days after sharp increases in the freshwater discharge, but the discharge peaks at the end of July induced only a small DSi increase at the beginning of August (Figs. 2, 4g). The discharge peaks at the beginning and at the end of July led to an increase in both BSi and DiatChla concentrations. However, the high discharge peak at the end of August resulted in an increase in BSi concentration $\left(364 \mu \mathrm{mol} \mathrm{L}^{-1}\right)$ but a decrease in DiatChla concentration $\left(92 \mu \mathrm{g} \mathrm{L}^{-1}\right)$ on 8 September 2003. At Temse and at Hemiksem (Fig. 4h, i), DSi was also consumed down to $5 \mu \mathrm{mol} \mathrm{L}{ }^{-1}$ in summer. However, the uptake started later and lasted for a shorter period at Hemiksem compared to Dendermonde and Temse. From June to August, BSi and DiatChla concentrations increased and correlated well at Temse and Hemiksem, but never reached the high levels observed at Dendermonde.
While the weather was summer-like in September 2003, the irradiance and the temperature dropped suddenly in October and the rainfall increased (IRMB 2003-2004). In October at Dendermonde, the DSi concentration increased rapidly following the discharge peak (Figs. 2, 4g). DSi was no longer consumed and remained high at about $200 \mu \mathrm{mol} \mathrm{L}{ }^{-1}$, while $\mathrm{BSi}$ and DiatChla started to decrease. In parallel to what was observed at Dendermonde, DiatChl $a$ concentrations at Temse were still high in September but declined from October onwards. At Hemiksem, DiatChla started to decline already in September. However, DSi concentrations reached winter levels only at the end of October at Temse and Hemiksem. Background levels of DiatChla lower than $10 \mu \mathrm{g} \mathrm{L}^{-1}$ were recorded only in February and March 2004 at Dendermonde, whereas such low concentrations were already reached in November at Temse and Hemiksem (Fig. 4g-i). At these two locations, BSi did not decrease in parallel with DiatChla, high BSi concentrations being even recorded on 13 and 27 October 2003 at Temse when the SPM concentration reached its highest values of respectively 249 and $409 \mathrm{mg} \mathrm{L}^{-1}$. At Hemiksem, BSi remained high in September, but declined from October onwards (Fig. 4i).

Fraction of the BSi associated with living diatoms

To determine to which extent BSi was associated with living diatoms and to estimate the BSi content in living diatoms, correlations between BSi and DiatChl $a$ were performed on datasets characterizing the productive period (May to October) at Dendermonde, Temse and Hemiksem. Concentrations profiles (Fig. 4a, g) indeed suggested a different BSi to DiatChl $a$ ratio in the spring diatom community. However, the correlations were weak $\left(r^{2}=0.22\right.$, 0.14 and 0.40 at Dendermonde, Temse and Hemiksem, respectively, $n=25$ ) due to the interfering presence of $\mathrm{BSi}_{\mathrm{det}}$. As $\mathrm{SPM}_{\text {nbld }}$ was not correlated to DiatChl $a$ at any of the three estuarine stations $\left(r^{2} \leq 0.01\right)$, multiple regressions between $\mathrm{BSi}$ and the two explicative variables DiatChla and SPM $_{\text {nbld }}$ (see "Materials and methods") were thus performed to distinguish $\mathrm{BSi}_{\text {liv }}$ from $\mathrm{BSi}_{\text {det }}$. $\mathrm{SPM}_{\text {nbld }}$ may have been further divided in organic and inorganic fractions to investigate the origin of $\mathrm{BSi}_{\mathrm{det}}$ using $\mathrm{POC}$ and DiatChl $a$ data and the $\beta$ ratios defined above, but 


\section{At the tidal limits:}

Zone 1:
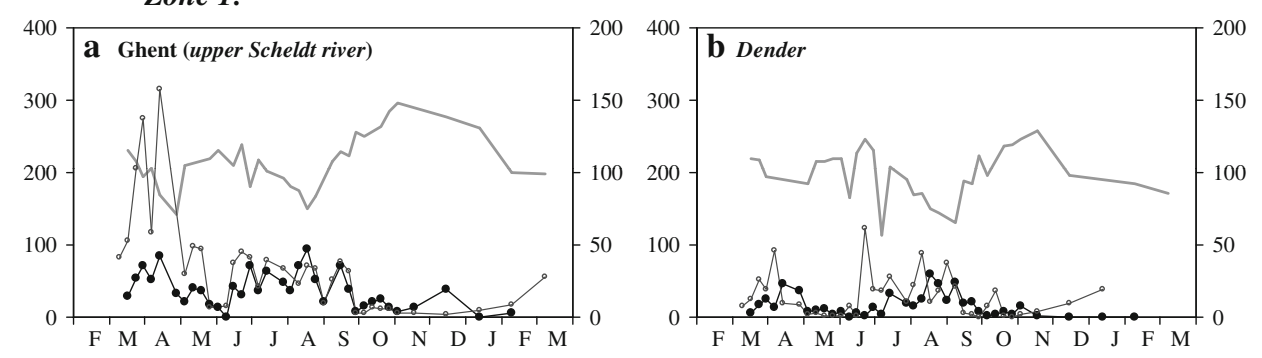

Zone 2:
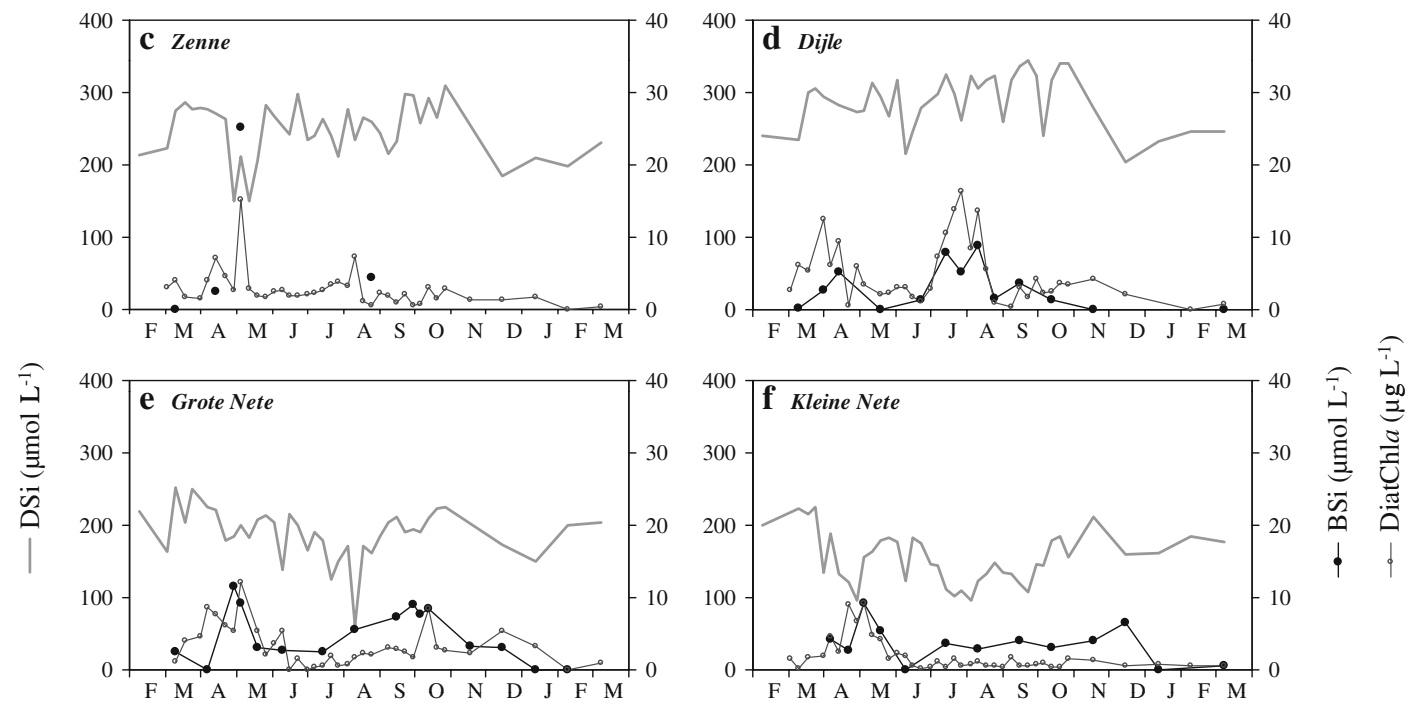

Along the tidal river:
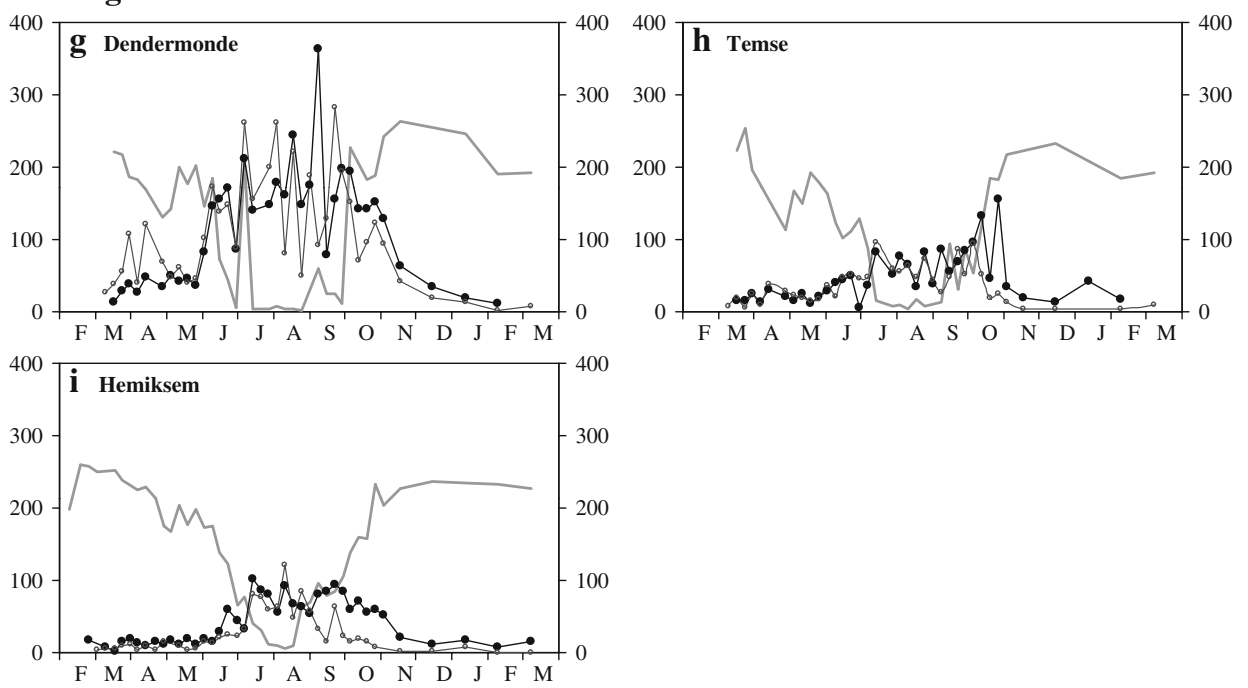

Fig. 4 DSi (left axis), BSi and DiatChla (right axis) concentrations at the nine sampling stations $(\mathbf{a}-\mathbf{i})$ from February 2003 to March 2004. Note the different scales for the BSi and

DiatChla concentrations for the tidal limits at Ghent, Dender, Zenne, Dijle, Grote and Kleine Nete (a-f) 
the correlation between organic and inorganic fractions $\left(0.54 \leq r^{2} \leq 0.88,23 \leq n \leq 25\right)$ ruled out the possibility to use both of them in the same multiple regression.

The $\mathrm{BSi}_{\text {liv }} /$ DiatChl $a$ ratio at Dendermonde, Temse and Hemiksem was, respectively $0.58 \pm 0.23$ $\mathrm{mol} \mathrm{g}^{-1}$ ( $\pm 95 \%$ confidence interval $), 0.68 \pm 0.15$ $\mathrm{mol} \mathrm{g}^{-1}$ and $0.71 \pm 0.15 \mathrm{~mol} \mathrm{~g}^{-1}$. Although $\mathrm{BSi}_{\mathrm{liv}} /$ DiatChla seemed to increase from Dendermonde to Hemiksem, it was not significantly different from one station to another ( $t$-test for equality: $0.56 \leq p \leq$ 0.76). The average $\mathrm{BSi}_{\mathrm{liv}} /$ DiatChl $a$ ratio of $0.67 \pm$ $0.11 \mathrm{~mol} \mathrm{~g}^{-1}$ estimated when lumping together the data from May to October at the three stations was not significantly different from those found at each station either ( $t$-test for equality: $0.34 \leq p \leq 0.99$ ). There was a good correlation between the BSi measured and that estimated by the regression $\left(r^{2}=0.71, n=75\right)$. Even, if the high-BSi data from 8 September 2003 at Dendermonde (Fig. 4g) was excluded from the regressions, $\mathrm{BSi}_{\mathrm{liv}} / \mathrm{DiatChl} a$ increased to $0.66 \pm 0.16 \mathrm{~mol} \mathrm{~g}^{-1}$ at Dendermonde ( $t$-test for equality with $\mathrm{BSi}_{\mathrm{liv}} / \mathrm{DiatChl} a$ at Temse and Hemiksem: $p=0.90$ and 0.75 , respectively). A better correlation between the measured and estimated $\mathrm{BSi}$ was then obtained when data from the three stations were lumped together $\left(r^{2}=0.83\right.$, $n=74)$ but the $\mathrm{BSi}_{\text {liv }} /$ DiatChla ratio did not change significantly $\left(0.68 \pm 0.07 \mathrm{~mol} \mathrm{~g}^{-1}, t\right.$-test for equality with $\mathrm{BSi}_{\text {liv }} /$ DiatChl $a$ at Dendermonde: $p=0.73$ ).

$\mathrm{BSi}_{\text {liv }}$ concentrations at the three estuarine stations during the productive period were therefore determined using a single $\mathrm{BSi}_{\text {liv }} /$ DiatChl $a$ ratio of $0.67 \mathrm{~mol} \mathrm{~g}^{-1}$. The $\mathrm{BSi}_{\text {liv }}$ fraction showed a high variability when calculated on a weekly basis, but was higher at Dendermonde and Temse than at Hemiksem as a general pattern (except in August) (Fig. 5). About $75 \%$ of the measured BSi at Dendermonde and Temse from May to July could be attributed to living diatoms, while only $50 \%$ at Hemiksem. From August onwards, the $\mathrm{BSi}_{1 \mathrm{iv}}$ fraction decreased at Dendermonde and Temse (but not lower than $50 \%$ at Dendermonde), while it reached its maximum in August at Hemiksem and decreased later to a value as low as $16 \%$ in October.

A similar multiple regression applied on lumped data from mid-March to end-May at Ghent and from mid-March to end-April at Dendermonde yielded a $\mathrm{BSi}_{\mathrm{liv}} / \mathrm{DiatChl} a$ ratio of $0.20 \pm 0.06 \mathrm{~mol} \mathrm{~g}^{-1}$ for the

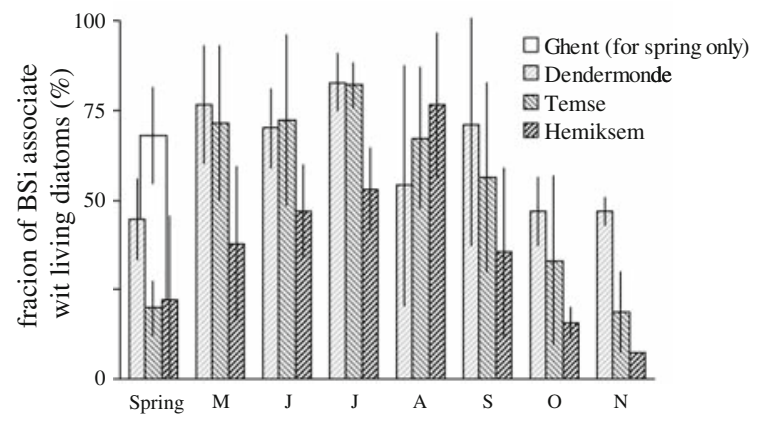

Fig. 5 BSi associated with living diatoms $\left(\mathrm{BSi}_{\text {liv }}\right)$ as a fraction of the total BSi concentration (error bars: \pm standard deviation, four measurements per month in general). The $\mathrm{BSi}_{\mathrm{liv}} / \mathrm{DiatChl} a$ ratios used for "Spring" (from mid-March to end-April) and for the period from May to November 2003 were respectively $0.20 \mathrm{~mol} \mathrm{~g}^{-1}$ and $0.67 \mathrm{~mol} \mathrm{~g}^{-1}$ (see text for details)

spring diatom community $\left(r^{2}=0.88, n=15\right)$. At Ghent, most of the BSi was associated with living diatoms, whereas most of the BSi was present as $\mathrm{BSi}_{\mathrm{det}}$ in the tidal river (Fig. 5).

Silica budget during the productive period

In order to assess the relative importance of $\mathrm{DSi}$, $\mathrm{BSi}_{\text {liv }}$ and $\mathrm{BSi}_{\text {det }}$ fluxes during the productive period (May to October 2003, 184 days), a silica budget was established (Fig. 6). The transfers between DSi, $\mathrm{BSi}_{\text {liv }}$ and $\mathrm{BSi}_{\text {det }}$ were also investigated to quantify diatom production and mortality as well as $\mathrm{BSi}$ settling.

The Scheldt tidal river received $260 \mathrm{Mmol}$ of silica (DSi $+\mathrm{BSi}$ ) during the productive period in 2003, predominantly in the dissolved form: total BSi inputs to the tidal river accounted for only $3 \%$ of this amount, mostly originating from the upper Scheldt river. The contribution of the Rupel tributaries to the total DSi input was $63 \%$.

In Zone 1a, there was a DSi uptake (40 Mmol) corresponding to nearly half of the DSi input flux (Fig. 6). Most of it remained in the $\mathrm{BSi}_{\text {liv }}$ pool and only one-fourth was transferred to the $\mathrm{BSi}_{\text {det }}$ pool. No settling but rather a resuspension of a small amount of BSi occurred in this zone. In Zone 1b, the opposite was observed: there was little DSi uptake but most of the $\mathrm{BSi}$ produced in Zone 1a settled in Zone $1 \mathrm{~b}$ (37 Mmol). Our data did not allow us to distinguish between $\mathrm{BSi}$ deposited as $\mathrm{BSi}_{\text {liv }}$ or $\mathrm{BSi}_{\text {det }}$. Indeed, settling of living diatoms could not be excluded. This 


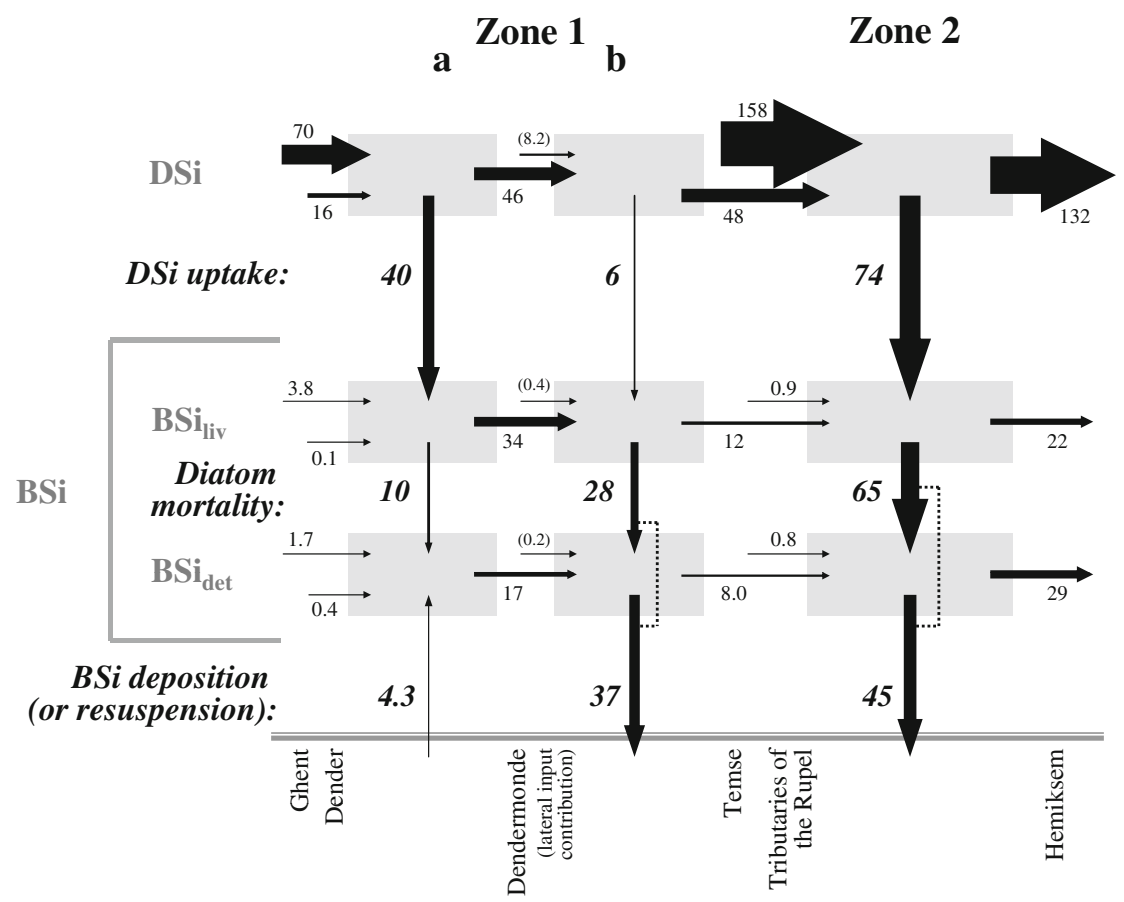

Fig. 6 Silica mass-balance (in Mmol) for the Scheldt tidal river over one productive period (May to October 2003, 184 days). Arrow thickness is proportional to the flux intensity. Horizontal arrows indicate DSi or BSi fluxes at each station. Lateral inputs for Zone 1a and 2 are not explicitly represented but redistributed among the tributaries (see text). For Zone 1b, the contribution of the lateral inputs is indicated in parentheses. Vertical arrows indicate productions or losses calculated as the difference, for each species, between the inputs and outputs in each zone. $\mathrm{BSi}_{\text {liv }}$ fluxes at Ghent and in the Dender were derived from $\mathrm{BSi}_{\mathrm{liv}}$ concentrations estimated by multiple linear regressions (see text). One should bear in mind that no discrimination was possible between $\mathrm{BSi}$ deposited as $\mathrm{BSi}_{\text {liv }}$ or as $\mathrm{BSi}_{\mathrm{det}}$, as indicated by the broken dashed line between "diatom mortality" and "BSi deposition" (see text) is indicated by the dotted line between the "diatom mortality" and the "BSi deposition" arrows in Fig. 6. Despite the settling of BSi in Zone 1b, the proportion between $\mathrm{BSi}_{\text {liv }}$ and $\mathrm{BSi}_{\text {det }}$ was similar at Dendermonde and at Temse. Overall, during the productive period in Zone 1, there was a BSi loss corresponding to $71 \%$ of the DSi uptake and a retention of $33 \%$ of the total amount of silica inputs to the zone.

Zone 2 received an important amount of DSi (206 Mmol at Temse) but ten times less BSi despite the important BSi production in Zone 1. Although the water surface area is similar in both zones (about $7 \times 10^{6} \mathrm{~m}^{2}$, Table 1), the DSi uptake, diatom mortality and BSi deposition in Zone 2 were all higher than in Zone 1. DSi uptake in Zone 2 amounted to $74 \mathrm{Mmol}$. Most of it was transferred to the $\mathrm{BSi}_{\text {det }}$ pool or deposited in this zone; the amount of $\mathrm{BSi}$ deposited amounted to $61 \%$ of the $\mathrm{BSi}$ produced (estimated from DSi uptake). Despite a higher amount of BSi deposited, the retention of silica in Zone $2(20 \%)$ was lower than in Zone 1 (33\%) due to higher DSi inputs in Zone 2. At the outlet of the tidal river, $\mathrm{BSi}$ accounted for $28 \%$ of the total silica pool (DSi + BSi).

Overall in the entire tidal river, $120 \mathrm{Mmol}$ of DSi were consumed, from which $65 \%$ were deposited as BSi, leading to a $30 \%$ retention of the total amount of silica that entered the Scheldt tidal river during the productive period. If compared to silica inputs, the relative DSi uptake and silica retention were higher in Zone 1 than in Zone 2. However the opposite was observed when considering absolute amounts of both DSi uptake and BSi loss: about $60 \%$ of the overall uptake and deposition occurred in Zone 2. 


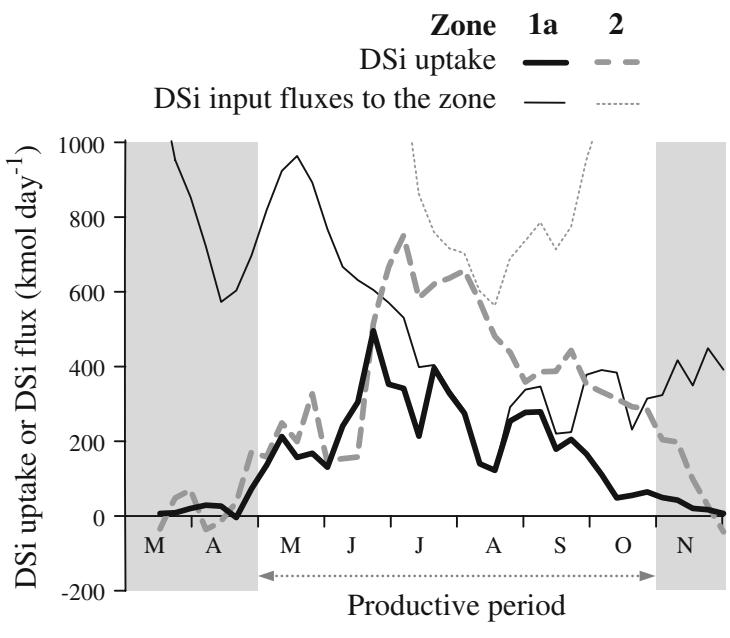

Fig. 7 Three-week moving average of weekly DSi uptake fluxes (in kmol day ${ }^{-1}$ ) in Zone 1a and Zone 2 from March to November 2003 (the 3-week moving averages were performed to smooth out artefacts possibly induced by the water residence time between adjacent stations). Uptake fluxes are indicated by positive values to allow the comparison with the DSi input fluxes to the zone (dotted and dashed lines). The latter correspond to the potential maximum for DSi uptake in the zone

Temporal evolution of the DSi uptake

In both zones, DSi uptake started in May and lasted until October/November (Fig. 7). In May and beginning of June, DSi uptake increased identically in both zones reaching $500 \mathrm{kmol} \mathrm{day}^{-1}$ in mid-June. At that point, DSi uptake started to decrease in Zone 1a while it continued to increase in Zone 2 reaching a value of about $800 \mathrm{kmol} \mathrm{day}^{-1}$ at the end of June. DSi uptake decreased in both zones from July until the end of the productive period, more or less at the same rate, but it always stayed higher in Zone 2 than in Zone 1a by about $250 \mathrm{kmol} \mathrm{day}^{-1}$.

If DSi is completely consumed, DSi uptake equals DSi input fluxes. Thus, the DSi input flux can be seen as a potential maximum for DSi uptake. This potential maximum was higher in Zone 2 than in Zone 1 and the observed DSi uptake was complete from mid-July until the end of September in Zone 1a, but only at the end of July and beginning of August in Zone 2.

Annual fluxes discharged to the brackish estuary

During our 1-year study period (7 February 2003-6 February 2004), the amount of water discharged

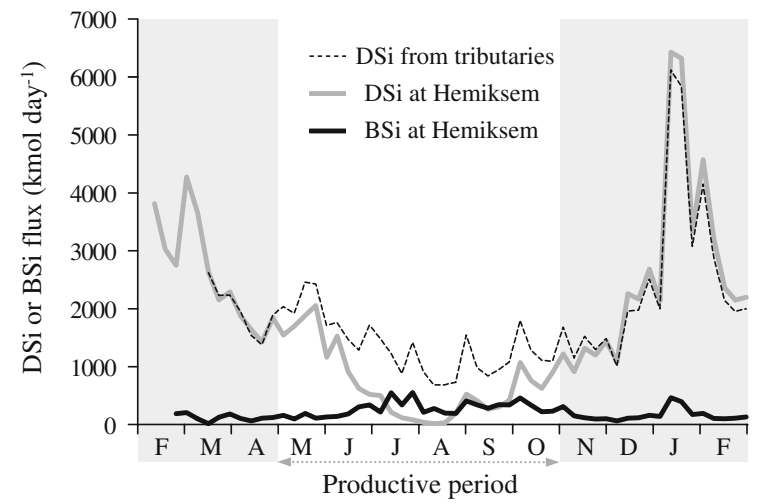

Fig. 8 Weekly DSi or BSi fluxes at Hemiksem from February 2003 to February 2004. DSi input in the tidal river is also indicated

Table 3 DSi and BSi fluxes (in Mmol) from the tributaries and at Hemiksem, for the productive period and at an annual timescale

\begin{tabular}{|c|c|c|c|c|}
\hline & Tributaries & Hemiksem & $\begin{array}{l}\mathrm{DSi} \\
\text { consumption } \\
(\%)\end{array}$ & $\begin{array}{l}\text { Silica } \\
\text { retention } \\
(\%)\end{array}$ \\
\hline \multicolumn{5}{|c|}{ Productive period (1 May 2003-30 October 2003, 184 days) } \\
\hline DSi & 252 & 132 & 48 & 30 \\
\hline $\mathrm{BSi}$ & 8.4 & 51 & & \\
\hline \multicolumn{5}{|c|}{ Annual fluxes (7 February 2003-6 February 2004) } \\
\hline DSi & 713 & 612 & 14 & 6 \\
\hline $\mathrm{BSi}$ & 21 & 80 & & \\
\hline
\end{tabular}

DSi consumption and total silica $(\mathrm{DSi}+\mathrm{BSi})$ retention for both periods are also given

during the productive period (6 months) was two times smaller than that discharged during the rest of the year. DSi concentrations in the tributaries did not exhibit important temporal variations (Fig. 4a-f), but fluxes of riverine DSi delivered to the tidal river showed a minimum in summer because of the lower discharge (Fig. 8). At the outlet of the tidal river near Hemiksem, the annual variations in the DSi flux were further enhanced by the effect of diatom uptake superimposed to that of the decreasing river discharge. Conversely, seasonal variations in discharge flattened the BSi fluxes pattern, which ranged from $100 \mathrm{kmol} \mathrm{day}^{-1}$ in spring/autumn/winter to $400 \mathrm{kmol} \mathrm{day}^{-1}$ in summer. The annual DSi uptake and silica retention corresponded to 14 and $6 \%$ of total inputs, respectively. This is 3-5 times smaller than the estimates characterizing the productive period (Table 3 ). 


\section{Discussion}

Distinction between $\mathrm{BSi}_{\text {liv }}$ and $\mathrm{BSi}_{\text {det }}$

In order to better investigate the dynamics of $\mathrm{BSi}$, a multiple linear regression was performed with the explicative variables DiatChl $a$ and SPM $_{\text {nbld }}$ (defined in Eq. 4) to distinguish between BSi associated or not with living diatoms. As the two explicative variables were very poorly correlated $\left(r^{2}=0.02, n=75\right)$, the discrimination could be regarded as robust. Admittedly, it could not be excluded that empty frustules followed the distribution of living diatoms, yielding an overestimation of the $\mathrm{BSi}_{\mathrm{liv}} / \mathrm{DiatChl} a$ ratio. However, $\mathrm{BSi}_{\text {liv }} /$ DiatChl $a$ was identical at Dendermonde, Temse and Hemiksem (see "Results"), despite the facts that large amounts of BSi settled between Dendermonde and Temse (Fig. 6) and mortality increased at Hemiksem (Fig. 5).

The use of the linear multiple regression model implied that $\mathrm{BSi}_{\text {liv }}$ was calculated using an average, constant $\mathrm{BSi}_{\mathrm{liv}} / \mathrm{DiatChl} a$ ratio. However, silica and/or chlorophyll $a$ contents in diatoms are known to exhibit important variations depending on nutrient availability, temperature and light conditions (Geider 1987; Ragueneau et al. 2000; Martin-Jézéquel et al. 2000; Hildebrand 2002). Due to the variations in DSi concentrations (Fig. 4g-i), light and temperature during the productive period, diatom cells in the Scheldt may thus not have had a constant content of silica and of chlorophyll $a$. But in our study, the $\mathrm{BSi}_{\text {liv }} /$ DiatChl $a$ ratio was not intended to be estimated at the cellular scale (which would not have been possible from our dataset), but at the system and seasonal scales, where the variations of the measured $\mathrm{BSi}$ concentrations were expected to depend more on the presence of detrital BSi than on the variation of the chlorophyll $a$ and BSi contents of the diatoms. The multiple regression model, although very simple, reproduced indeed well the variations in $\mathrm{BSi}$ concentrations even if the data from the three estuarine stations were lumped together: the correlation between estimated and measured BSi was good $\left(r^{2}=0.71\right.$ if $n=75$, or $r^{2}=0.83$ if $n=74$, see "Results") and the $95 \%$ confidence interval associated with the $\mathrm{BSi}_{\text {liv }} /$ DiatChl $a$ ratio was rather narrow ( $\pm 16 \%$ if $n=75$, or $\pm 11 \%$ if $n=74$ ).

The $\beta_{\mathrm{POC} / \mathrm{Chl} a}$ and $\beta_{\mathrm{OM} / \mathrm{POC}}$ conversion factors were used to subtract the SPM concentration from the contribution of diatom biomass which was already represented in the multiple regression by the other explicative variable, DiatChl $a$ (Eqs. 4, 5). Due to the important fraction of non-phytoplankton organic matter in the SPM of the Scheldt tidal river (Hellings et al. 1999), these two factors could not be estimated from our dataset and average constant ratios were taken from the literature. In particular, $\beta_{\mathrm{POC} / \mathrm{Chl} a}$ may display important variations (Geider 1987). However, although a variation in these ratios can affect the estimation of the $\mathrm{BSi}_{\text {liv }} /$ DiatChla ratio ( $k_{1}$ in Eq. 5), their influence was not expected to be important. Using Eq. 4, Eq. 5 can indeed be rewritten as:

$$
\begin{aligned}
\mathrm{BSi}= & \left(k_{1}-k_{2} \cdot \beta\right) \cdot \text { DiatChl } a+k_{2} \\
& \cdot\left(\mathrm{SPM}-\mathrm{BSi} \cdot \mathrm{M}_{\mathrm{BSiO}_{2}}\right)
\end{aligned}
$$

with $\beta=\beta_{\mathrm{POC} / \mathrm{Chl} a} \cdot \beta_{\mathrm{OM} / \mathrm{POC}}$

In this study, $\beta$ was equal to 75 . The use of another $\beta$ value would indeed induce a different $k_{1}$, but $k_{2}$ and the correlation between the measured BSi concentrations and those estimated by the regression would not be altered. Furthermore, as $k_{2}$ was $0.48 \mathrm{mmol} \mathrm{g}^{-1}$ when $n=75\left(k_{2}=0.42\right.$ when $n=74$, cf. above), the relative variation would be 19 times smaller for $k_{1}$ than for $\beta$.

In addition, using $\beta_{\mathrm{POC} / \mathrm{Chl} a}$, our $\mathrm{BSi}_{\text {liv }} /$ DiatChl $a$ ratio would correspond to a $\mathrm{Si} / \mathrm{C}$ molar ratio in living diatoms of 0.27 ( \pm 0.04$)$, which would fall in the range observed in Cyclotella meneghiniana cultures (0.38, Sicko-Goad et al. $1984 ; 0.12-0.30$ for several cultures of two Cyclotella sp. strains isolated from the Scheldt, Carbonnel 2009).

Phytolith contribution to the BSi pool

$\mathrm{BSi}$ is not produced by diatoms only. Higher plants can also take up DSi and form BSi particles called phytoliths (Conley 2002), which can contribute significantly to the BSi pool in rivers (Cary et al. 2005). The Scheldt tidal river is connected to $4.5 \mathrm{~km}^{2}$ of marshes, where vegetation and sediments represent large reservoirs of $\mathrm{BSi}$ as phytoliths (Struyf et al. 2005). At each tide, significant amounts of DSi and $\mathrm{BSi}$ are exchanged between the river main channel and these adjacent marshes (Struyf et al. 2006). Phytoliths may therefore be present in water samples taken in the main river. Most of the measured BSi was attributed to living diatoms (Fig. 5) and 
phytoliths would be included in the $\mathrm{BSi}_{\text {det }}$ pool, as higher plants do not contain the pigments that were used as markers for diatoms (Lionard et al. 2008a). Unfortunately, no microscopic investigation was performed to partition $\mathrm{BSi}_{\text {det }}$ (diatom frustules vs. phytoliths), but several indications suggest that the contribution of phytoliths is not significant.

Among the vegetation bordering the tidal river, reeds have by far the highest silica content (Struyf et al. 2005): $7 \%$ of Si per dry weight in dead shoots, but, due to the fact that phytoliths dissolve faster than plant tissues, the maximum silica content found in reed litter is 4\% (Struyf et al. 2005, 2007a). Considering a marsh surface area of $4.5 \mathrm{~km}^{2}$ (Struyf et al. 2005) occupied at $55 \%$ by reeds (Soetaert et al. 2004), it would produce annually detritus amounting to $134 \mathrm{Mmol}$ of carbon (Soetaert et al. 2004). With a $4 \% \mathrm{Si}$ content per dry weight, this would correspond to $6.1 \mathrm{Mmol}$ of $\mathrm{BSi}$ as phytoliths. Given a $100 \%$ annual turnover of the aboveground vegetation (Soetaert et al. 2004), this is in agreement with the maximum estimate of BSi stock in aboveground biomass (Struyf et al. 2005). This amount is small compared to the BSi fluxes during the productive period (Fig. 6) and cannot account for the increase of $\mathrm{BSi}_{\text {det }}(26 \mathrm{Mmol}$ for the entire tidal river, Fig. 6). Furthermore, for all tidal cycles investigated by Struyf et al. (2006), the net transport of BSi was always from the river channel to the marsh, and there were six times more diatom frustules than phytoliths in marsh sediments (Struyf et al. 2005). Marshes thus appear to be, at first sight, rather a sink for estuarine BSi than a source of phytoliths to the main channel.

Reed detritus are nevertheless common in the SPM of the Scheldt tidal river (Lionard et al. 2008a) and phytoliths could be brought by soil erosion. Phytoliths distribution in soils is closely related to that of soil organic matter (Alexandre et al. 1997; Blecker et al. 2006) and organic matter decomposes faster than the phytoliths in immerged reed detritus (Struyf et al. 2007a). The organic matter from soil and vegetation was thus considered as an indicator of the possible presence of phytoliths. Abril et al. (2002) estimated this organic matter fraction to amount to $23 \%$ of the non-phytoplankton POC in the tributaries; in the tidal river, a similar content was supposed for the POC not corresponding to living diatoms $\left(\mathrm{POC}_{\mathrm{nld}}\right.$, estimated by difference using $\mathrm{POC}$ and DiatChla data and $\beta_{\mathrm{POC} / \mathrm{Chl} a}=30$ ). However, the

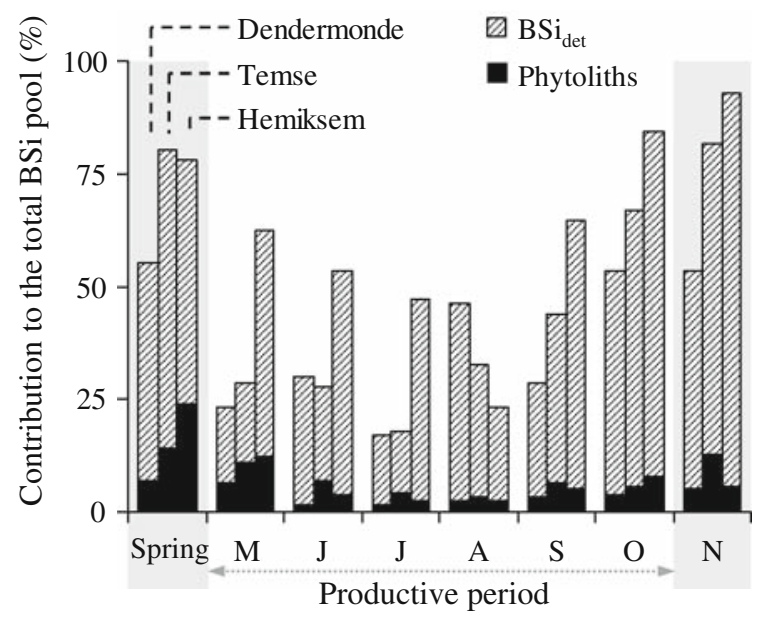

Fig. 9 Average monthly contributions of $\mathrm{BSi}_{\text {det }}$ and phytoliths to the BSi pool at the three estuarine stations in "Spring" (from mid-March to end-April) and from May to November 2003. The contribution of phytoliths was calculated assuming a $\mathrm{Si}$ content of $4 \%$ dry weight and a POC from vegetation and soil corresponding to $23 \%$ of $\mathrm{POC}_{\text {nld }}$ (see text)

amount of phytoliths estimated from such a POC fraction would only contribute to about $14 \pm 10 \%$ of the $\mathrm{BSi}_{\mathrm{det}}$ or $5 \pm 3 \%$ of the total $\mathrm{BSi}$ pool during the productive period, even with a $\mathrm{Si}$ content of $4 \%$ per dry weight as found in reed litter (Fig. 9). This content is indeed in the high range of the average values generally observed (1-3\%; Conley 2002; Blecker et al. 2006). It is however acknowledged that phytoliths may become an important, if not the major, constituent of the BSi pool in the winter season due to lower diatom production but higher litter fall and precipitations (which enhance the soil erosion).

Accuracy and precision of the DSi and BSi fluxes and mass-balance calculation

A source of imprecision in our mass-balance calculation may arise from the fact that integrated seasonal fluxes were estimated from discrete weekly DSi and BSi measurements. Selecting a method for evaluating annual riverine fluxes from such concentration datasets is a controversial subject (Kronvang and Bruhn 1996; Moatar and Meybeck 2005, 2007). Kronvang and Bruhn (1996) and Moatar and Meybeck (2005) tested several methods with different sampling strategies on high frequency datasets. They found that inaccuracy and imprecision could respectively reach 20 and $100 \%$. Unfortunately, no high frequency 
dataset was available in the Scheldt to test the accuracy of our integration method. Nevertheless, the values reported in Fig. 6 differ by less than $2 \%$ compared to the fluxes estimated when the often recommended "linear integration" method (Kronvang and Bruhn 1996; Moatar and Meybeck 2005) was applied to our data. Additionally, following Moatar et al. (2006) and Moatar and Meybeck (2007), all DSi and BSi fluxes provided by this latter method would be accurate (less than $0.3 \%$ deviation) but with a precision of about 10-20\% (flux weighted average: 12 and $8 \%$ for DSi and BSi, respectively). As both methods led to similar results, it could thus be assumed that the values for DSi and BSi fluxes shown in Fig. 6 were calculated with similar precisions. However, a lower precision can be expected for BSi due to analytical errors (10\%, Ragueneau et al. 2005), and above all to the complex SPM dynamics at the tidal scale (Chen et al. 2005a), which cannot be resolved by weekly sampling. Note that the partition between $\mathrm{BSi}_{\text {liv }}$ and $\mathrm{BSi}_{\text {det }}$, which was discussed in a previous section, influences the precision of the "diatom mortality" fluxes only, but not the "BSi deposition" fluxes. As a result, with such an overall precision, the BSi resuspension in Zone 1a and the DSi uptake in Zone 1b do not appear to be significant as they could result from the imprecision in the determination of the fluxes.

Despite low BSi concentrations and low BSi contents in the SPM (annual averages ranging from 1.3 to $3.2 \%$ ), the method used for BSi determination was considered as applicable in the case of the Dijle and the Grote and Kleine Nete. BSi and DiatChla concentrations in these rivers displayed indeed concomitant variations (Fig. 4d-f) although correlation coefficients were low $\left(0.11 \leq r^{2} \leq 0.56,13 \leq n\right.$ $\leq 15$ ). On the contrary, Eq. 3 gave negative correlation for the Zenne (data not shown) probably due to the presence of particulate material brought by the (at that time still) untreated wastewater from the city of Brussels. The Zenne however contributes to less than $10 \%$ of the total water discharge. Also, BSi concentrations in the tributaries of the Rupel were not measured weekly, but weekly fluxes were calculated from linear regressions with DiatChl $a$ despite weak correlations. Thus a higher level of uncertainty can be expected for the BSi input flux to the Rupel. However, the importance of this flux is limited when compared to the other fluxes in Fig. 6.
Another source of imprecision in the budget shown in Fig. 6 is linked to the estimation of DSi and BSi concentrations in lateral inputs, which were assumed identical to those found in the adjacent rivers. Lateral inputs were negligible for BSi but significant for DSi (Fig. 6). This is in line with the observation that $80 \%$ of the lateral DSi input fluxes are through precipitation and run-off in the brackish estuary (Soetaert et al. 2006) and that a similar origin may be assumed for the tidal river. The rest of the lateral input fluxes comes from industrial and domestic wastes, in which the DSi concentration is twice higher than that measured in the tributaries (Soetaert et al. 2006). Therefore, with lateral inputs contributing $10 \%$ of the total freshwater discharge and assuming that DSi concentrations in runoff waters are similar to those measured in the tributaries, taking into account the higher DSi concentrations in wastes would lead to an extra DSi input which would amount to only $1 \%$ of the total DSi inputs to the tidal river. However, one could consider that the origin of the lateral inputs to the tributaries was similar to those of the tidal river, so that DSi concentrations measured in the tributaries already reflect the contribution of industrial and domestic wastes.

With respect to the nature of the soils in the Scheldt basin, groundwater inputs are not expected to play a significant role either (Jacobs et al. 2008). Delstanche (2004) gathered 206 values of DSi concentrations in groundwater and first order streams in the Belgian watershed of the Scheldt. Although the values ranged from 10 to $920 \mu \mathrm{mol} \mathrm{L}{ }^{-1}, 80 \%$ of the measurements were between 100 and $400 \mu \mathrm{mol} \mathrm{L}{ }^{-1}$, with an average value of $270 \mu \mathrm{mol} \mathrm{L}{ }^{-1}$, similar to the level observed in the main tributaries of the Scheldt.

Importance of BSi dissolution and DSi recycling

The mass-balance estimations shown in Fig. 6 give only an overall picture of the processes occurring between the sampling stations. An internal cycle of silica comprising dissolution, uptake and settling cannot be excluded and would lead to a higher gross DSi uptake and BSi settling. Dissolution could potentially take place in the sediments but also in the water column as it contains a significant amount of $\mathrm{BSi}_{\text {det }}$ (Figs. 5, 6).

Roubeix et al. (2008) measured a BSi specific dissolution rate of $0.084 \mathrm{day}^{-1}$ in cultures of 
C. meneghiniana and bacteria originating both from the Scheldt tidal river. However, BSi dissolution rates can be lowered by the incorporation of aluminium in the BSi matrix (Van Cappellen et al. 2002). Roubeix et al. (2008) did not investigate aluminium, but concentrations of $1-2 \mu \mathrm{mol} \mathrm{L}{ }^{-1}$ were measured in February 2003 in the tidal river (Carbonnel 2009). At aluminium concentrations higher than $200 \mathrm{nmol} \mathrm{L}^{-1}$, diatoms may build frustules with an $\mathrm{Al} / \mathrm{Si}$ atomic ratio of 0.01 (Van Beusekom 1991, cited in Van Cappellen et al. 2002). Such a ratio would result in a BSi dissolution rate as low as $0.001 \mathrm{day}^{-1}$, about 70 times lower than the rate observed for frustules of diatoms grown in aluminium-poor medium when normalised to specific surface area (Van Cappellen et al. 2002). Even higher $\mathrm{Al} / \mathrm{Si}$ ratios may be reached by $\mathrm{Al}$ incorporation in the $\mathrm{BSi}$ matrix after diatom death (Van Cappellen et al. 2002). As a result, the specific dissolution rate can be expected to be, at least, as low as $0.0012 \mathrm{day}^{-1}$ in the Scheldt tidal river. Less than $1-2 \%$ of the $\mathrm{BSi}$ would then be dissolved considering the average residence times of water presented in Table 1.

Struyf et al. (2006) found that marshes act as silica recyclers and that the flux of DSi exported from the $4.5 \mathrm{~km}^{2}$ of marshes bordering the Scheldt tidal river may exceed the flux entering the river system when DSi concentration and freshwater discharge are low. Indeed, the average DSi flux at Dendermonde was as low as $6 \mathrm{kmol} \mathrm{day}^{-1}$ at the end July and beginning of August 2003 (this study). However, this recycling is of minor importance compared to the riverine DSi inputs during the productive period (Fig. 6): by extrapolation, recycling would amount to $8 \pm 3 \mathrm{Mmol}$ of DSi according to the rates measured by Struyf et al. (2006) during the productive period in 2002 and 2003 in a marsh located close to the mouth of the Durme (Fig. 1). Using model simulations, Arndt and Regnier (2007) estimated that, during the productive period in 2003, the highest recycling rates occurred indeed in Zone $1 \mathrm{~b}$. They found that riverine inputs and silica recycling could be of the same order of magnitude, but only in mid-August 2003. Taking spatial heterogeneity into account, they however estimated that only $2 \mathrm{Mmol}$ of DSi would be recycled between Ghent and the mouth of the Rupel between June and November. As a result, less than $1 \%$ of the overall diatom production over the productive period could be sustained by recycled DSi (Arndt and
Regnier 2007). Considering that this amount was calculated with a BSi dissolution rate 25 times higher than what would be expected for BSi containing $1 \%$ aluminium, it can be concluded that BSi dissolution is not expected to play a significant role in the silica dynamics within the tidal river during the selected study period.

DSi uptake in Zones 1 and 2 and influence of the freshwater discharge

The high DSi uptake in Zone 2 (Fig. 6) revealed an important diatom growth, although this was not expected because of short water residence times in the Rupel and its tributaries (Table 1) and of possible light limitation near and downstream of the confluence with the Rupel. Indeed, the section of the Scheldt comprised between Temse and Hemiksem contributes to roughly half of the water surface area and of the volume of Zone 2 (Fig. 1; Table 1). But near the mouth of the Rupel, the presence of a water energy maximum results in high SPM concentrations and a longer residence time of riverborne material (Chen et al. 2005a), and water column deepens downstream of the confluence (Table 1; Muylaert et al. 2005). However, diatom growth might have occurred between Temse and the mouth of the Rupel, where the water depth is still shallow and where the diatom-rich but DSi-depleted Scheldt water receives DSi from the Rupel due to tidal mixing. A diatom bloom might have additionally occurred in the shallow Nete (Table 1) because of exceptionally low water discharges during summer 2003 $\left(<30 \mathrm{~m}^{3} \mathrm{~s}^{-1}\right)$. A local maximum in diatom production in the lower part of the Nete was indeed predicted by the model simulation of Arndt et al. (2007) during summer 2003 (S. Arndt, personal communication). In August 1995, when discharge in the Scheldt tidal river was similar to that in 2003, the diatom biomass in the Nete was also among the highest of the tidal river (Muylaert et al. 1997).

The comparison of the DSi consumption in Zone 1 and 2 illustrated the influence of the discharge on the diatom production: a higher discharge in Zone 2 than in Zone 1 resulted in higher DSi inputs and also a higher diatom production in Zone 2 (Fig. 6). This can be explained by the fact that DSi was entirely consumed from June to September in Zone 1a (except however for periods following the discharge peaks, 
Fig. $4 \mathrm{~g}$ ), whereas this was the case only at the end July and beginning of August in Zone 2 (Fig. 4i). In both zones, DSi concentrations could drop below $5 \mu \mathrm{mol} \mathrm{L}{ }^{-1}$. Such low levels could limit the diatom production, as half-saturation constants for the growth of two strains of Cyclotella sp. isolated from the Scheldt were found to be 4 and $13 \mu \mathrm{mol} \mathrm{L}^{-1}$ of DSi (K. Muylaert, unpublished data). During these periods, DSi uptake corresponded thus to the DSi inputs to the zones and, in particular, a minimum of DSi uptake in Zone 1a in August was induced by a low water discharge (Fig. 7). The higher DSi inputs in Zone 2 as compared with Zone 1a resulted in a shorter period of potential DSi limitation in Zone 2. Also, during the periods of potential DSi limitation, the DSi uptake rate in Zone 2 was limited at a higher rate than in Zone 1a (Figs. 6, 7). A low water discharge can thus induce a low rate of diatom production due to DSi limitation. In contrast, it has already been shown that a high discharge may hamper diatom growth by flushing the diatoms out of the zone (Muylaert et al. 2001, 2005; Arndt et al. 2007). If all factors influencing diatom growth other than silica availability and discharge are kept constant, an optimal discharge can be found at which the highest diatom production is reached, as shown by model simulations carried out on Zone 1 during summer 2003 by Arndt et al. (2007). This phenomenon was also observed on an inter-annual timescale by Peterson et al. (1985) in the San Francisco estuary.

The summer of 2003 was exceptionally dry, warm and sunny (IRMB 2003-2004) and during this period the Scheldt discharge was the lowest for the decade 1996-2005 (56 $\mathrm{m}^{3} \mathrm{~s}^{-1}$, average 1996-2005: $\left.77 \mathrm{~m}^{3} \mathrm{~s}^{-1}\right)$. DSi uptake and silica retention reached high values: 48 and $30 \%$, respectively during the productive period (Table 3 ). This is comparable to the DSi retention estimated by Garnier et al. (2002) for the Seine tidal river during the summer of a dry year (47\% in 1993). Summer diatom production and silica uptake are however expected to vary from 1 year to another: the percentage of DSi consumed should indeed decrease with increasing discharge and decreasing water residence times, as observed by Garnier et al. (2002) in the Seine at an inter-annual timescale. For the period 1996-2000, Struyf et al. (2004) also observed increasing summer DSi concentrations with increasing discharge in the Scheldt at Dendermonde, whereas winter DSi concentrations stayed constant at about $230 \mu \mathrm{mol} \mathrm{L}{ }^{-1}$. At highest summer discharges, the DSi concentrations could even reach winter DSi concentrations. Accordingly, Van Damme et al. (2005) reported that almost no DSi was consumed in the tidal river during the wet and mostly overcast summer 2000. Lionard et al. (2008b) found a negative correlation between the summer phytoplankton biomass and the summer discharge for the period 1996-2004. The summer DSi concentrations also decreased with increasing summer phytoplankton biomass, except however for the years 1996 and 1999 (Lionard et al. 2008b). This highlights the fact that parameters other than discharge may play a role in regulating inter-annual variations of the summer DSi concentrations.

At a seasonal timescale and for the entire tidal river, a decreasing trend could be observed between DSi uptake and discharge, but the relationship did not appear strongly linear and, above all, highlighted the fact that DSi uptake dropped from 100 to $30 \%$ from August to October even though the 3-week moving average discharge stayed between 40 and $60 \mathrm{~m}^{3} \mathrm{~s}^{-1}$ (Fig. 10). This suggests that discharge was not the only controlling parameter for DSi uptake in the tidal river at this timescale. As in many estuarine systems, light availability is a major factor influencing phytoplankton productivity in the Scheldt (Muylaert et al. 2005; Arndt et al. 2007). The seasonal variation of light during the productive period in 2003 was uncorrelated to discharge (3-week moving average data: $r^{2}=0.06, n=26$ ) and the drop in DSi uptake from August to October could actually be attributed to the decrease of the incident light (IRMB 20032004). When the multiple regression was performed between DSi uptake and the explicative variables discharge and light, the correlation coefficient $\left(r^{2}=\right.$ $0.80, n=26$ ) was significantly improved compared to that of the regression shown in Fig. 10 and the residuals of the regression did not exhibit any significant pattern.

Parameters other than discharge, light and DSi availability might have influenced diatom growth and thus DSi uptake. Limitation by nutrients other than DSi could be ruled out in the tidal river as dissolved nitrogen and phosphorus were in high concentrations during the study period (Van der Zee et al. 2007). The diatom productivity should not have been controlled by the zooplankton community, which is dominated by rotifers in the Scheldt tidal river (Muylaert et al. 


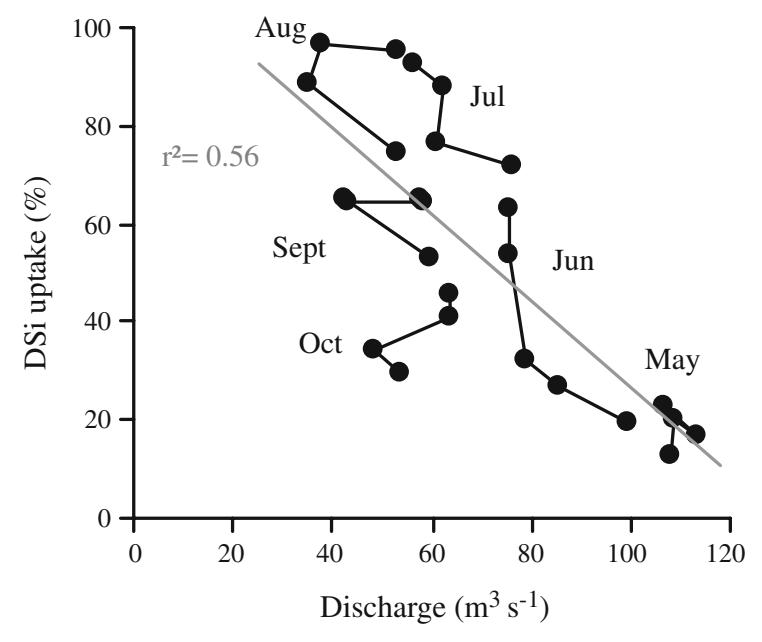

Fig. 10 DSi uptake (\%) in the entire tidal river in 2003, estimated from DSi fluxes in the tributaries and at Hemiksem, versus discharge $\left(\mathrm{m}^{3} \mathrm{~s}^{-1}\right)$. All values are 3-week moving average

2005 and reference therein). The phytoplankton biomass can have however a strong influence on phytoplankton productivity (Muylaert et al. 2005). The 3-week moving average of the biomass at Dendermonde, Temse and Hemiksem correlated well with the percentage of DSi consumed $\left(r^{2}=0.81\right.$, $n=26$ ). But, biomass also depends on light and discharge in the Scheldt tidal river (multiple linear regression: $r^{2}=0.74, n=26$ ) and its effects should therefore already be implicitly included when the influence of light is taken into account.

Spatial distribution of the BSi deposition:

influence of the SPM dynamics

The absence of correlation between DiatChl $a$ and $\operatorname{SPM}_{\text {nbld }}\left(r^{2}=0.02, n=75\right)$ tends to prove that living diatoms do not follow the SPM dynamics. However, the multiple regression between $\mathrm{BSi}$ and the two aforementioned independent variables provided a stronger correlation $\left(r^{2}=0.71, n=75\right)$ than that between BSi and DiatChla only $\left(r^{2}=0.51\right.$, $n=75$ ). It indicates that BSi and SPM dynamics are nevertheless linked to some extent. As a consequence, BSi concentrations in the estuary may exhibit vertical gradients, tidal deposition/resuspension cycles and tidal variations as it is the case for estuarine SPM, even if this SPM heterogeneity is less pronounced upstream of the confluence with the
Rupel than downstream, in the zone of maximum of turbidity (Chen et al. 2005a). These processes could not be considered in our study due to the sampling frequency and to the fact that only surface water samples were taken.

The longitudinal distribution of the BSi deposition over Zone 2 could not be assessed due to the absence of an intermediate sampling station. In Zone 1, DSi uptake and BSi deposition occurred in different subzones (Fig. 6). Arndt and Regnier (2007) indeed predicted that BSi deposition should occur in Zone $1 \mathrm{~b}$ throughout the productive period, which is in agreement with our budget. These authors also found that a smaller amount of BSi would be deposited in Zone 1a, but only in August when diatom production was shifted upstream of Dendermonde due to silica limitation. Furthermore, Arndt et al. (2007) predicted that the maximum diatom production should be located in Zone $1 \mathrm{~b}$ in June because of lower SPM concentrations. In contrast, our findings rather suggest that the diatoms bloomed at Dendermonde or further upstream (Zone 1a) during the whole productive period and were subsequently transported downstream. DiatChl $a$ was always higher at Dendermonde than at Temse. Except maybe during the first week of July because of a discharge peak, DSi was already completely consumed in June at Dendermonde (Fig. 4g, h). In October, the DSi uptake nevertheless occurred in Zone 1b (Fig. 4g, h).

Deposition in Zone 1a cannot however be excluded. SPM dynamics are driven by a complex hydrodynamic energy pattern determined by the convergence of the decreasing energies of riverine and marine origins, and by the channel morphology (Chen et al. 2005a; Arndt et al. 2007). Although there is a net downstream transport of SPM in the upstream part of the tidal river, a high fluvial hydrodynamic energy induces a turbidity maximum in Zone 1a, and a local energy minimum is observed in Zone $1 \mathrm{~b}$ (Chen et al. 2005a; Arndt et al. 2007). Despite a high temporal variability, the average measured SPM concentrations was indeed significantly higher at Dendermonde $\left(97 \pm 61 \mathrm{mg} \mathrm{L}^{-1}\right.$, mean $\left.\pm \mathrm{SD}\right)$ than at Temse $\left(69 \pm 71 \mathrm{mg} \mathrm{L}^{-1}\right.$, $t$-test for equality: $p=0.08)$ or in the rivers Scheldt $\left(32 \pm 9 \mathrm{mg} \mathrm{L}^{-1}\right.$, $\left.p=3 \times 10^{-8}\right)$ and Dender $\left(15 \pm 8 \mathrm{mg} \mathrm{L}^{-1}, p=\right.$ $\left.10^{-11}\right)$. The presence of a turbidity maximum at or upstream of Dendermonde indicates an increased residence time leading to the retention or accumulation of 
suspended particles in this area. A consequence of the BSi accumulation in Zone 1a is that both the BSi flux at Dendermonde and the deposition in Zone 1b may have been lower than what we estimated (Fig. 6). Nevertheless, this would have altered only the spatial repartition of the deposition of BSi within Zone 1, but not the estimation of its overall amount.

The important deposition estimated for Zone $1 \mathrm{~b}$ is supported by the presence of the hydrodynamic energy minimum, which induces lower particle concentrations (Chen et al. 2005a; Arndt et al. 2007). Additionally, deposition in Zone 1b may have been enhanced by the deepening and widening of the channel and by the increase of the residual current (Table 1). A decoupling between BSi and the rest of the SPM could however be observed at this stage as the average BSi content during the productive period was significantly higher at Dendermonde (10.5 \pm $7.0 \%$, mean \pm SD) than at Temse $(6.0 \pm 2.8 \%)$ ( $t$-test for equality: $p=0.004)$. This suggests a preferential settling of $\mathrm{BSi}$ compared to non-BSi SPM in Zone 1b. This may be due to the fact that the SPM in the Scheldt tidal river is composed of more than half of clay material ( $<4 \mu \mathrm{m}$; Chen et al. 2005b), which are finer than diatom frustules and thus expected to remain in suspension for a longer time (cultures of $C$. meneghiniana isolated from the Scheldt exhibited cell sizes ranging from 10 to $25 \mu \mathrm{m}, \mathrm{V}$. Roubeix, personal communciation). In addition, the presence of organic material around diatoms would enhance their aggregation into flocs and increase their sinking rate (Chen et al. 2005b).

Most of the BSi deposition should occur in shallow areas, such as tidal mudflats, tidal marshes and shallow parts of the river section, because of lower currents than in the main stream channel (Arndt and Regnier 2007). Struyf et al. (2006, 2007b) measured summer BSi deposition rates in two marshes along the Scheldt tidal river. All together, individual measurements varied within two orders of magnitude. The high variability could be explained by the fact that SPM deposition in marshes varies exponentially with the maximum tidal height, the marsh elevation and the distance to the creek or to the marsh edge (Temmerman et al. 2003). If the rates for the two marshes were averaged and extrapolated to a $4.5 \mathrm{~km}^{2}$ marsh surface area (Struyf et al. 2005), they would give an overall $\mathrm{BSi}$ deposition of $1.3 \pm 1.1$ and $15.0 \pm 14.6 \mathrm{Mmol}$ for the entire tidal river during the productive period. This would suggest that most of the $77 \mathrm{Mmol}$ of BSi deposition would have taken place in other areas such as shallow parts of the stream channel, mudflats or at the marsh edges. Mudflats represent about 39\% of the length of the tidal river banks, whereas marshes account for $32 \%$ (Meire et al. 2005). However, BSi deposited on mudflats or at marsh edges might be re-suspended in winter by higher water currents and re-deposited further inland in marshes. Together with higher winter SPM deposition (Temmerman et al. 2003), winter $\mathrm{BSi}$ deposition rates in marshes are indeed higher than the summer ones (Struyf et al. 2007b).

Silica fluxes at the annual timescale

In 2003, almost $80 \%$ of the annual amount of DSi was delivered to the brackish estuary outside the productive period (November-April, Table 3). Despite high $\mathrm{BSi}$ concentrations in the tidal river (Fig. 4), almost $90 \%$ of the silica discharged annually to the brackish estuary was in the form of DSi (Table 3). Diatom production occurred when silica input fluxes to the estuary were at their lowest values (Fig. 8). As a result, annual silica retention and DSi uptake were less than foreseen when only concentrations were examined (Fig. 4i) or when only the productive period was investigated (Fig. 6; Table 3).

Outside the productive period, sampling was performed at a monthly frequency. Following Moatar et al. (2006) and Moatar and Meybeck (2007), this would lead to an imprecision of about $30 \%$ on all annual DSi and BSi fluxes. Such an imprecision would preclude the comparison of the net annual amounts of DSi consumed and BSi produced over the entire tidal river with the net seasonal values (Table 3). Nevertheless, DSi displayed a conservative behaviour outside the productive period, whereas some more BSi was produced (Fig. 9; Table 3). Most of this production was attributed to late diatom activity in November and/or resuspension during the very high discharge event around mid-January (Figs. 2, 4g-i and 8). The spring bloom had no significant effect on the silica cycle in the tidal river. A mass-balance constructed for the period from midMarch to end-April suggested that DSi was not significantly affected along the estuary, with only $2 \mathrm{Mmol}$ of BSi produced in Zone 1a and settled in 
Zone $1 \mathrm{~b}$ : the spring bloom is imported from the upper Scheldt river and cannot develop in the tidal river (Muylaert et al. 2000, 2005). In our data, high DiatChla concentrations were measured in spring at Ghent and Dendermonde, but not further downstream (Fig. 4a, g-i).

The brackish estuary received an almost constant BSi flux compared to the DSi flux which could vary over more than two orders of magnitude (Fig. 8). This seasonal asymmetry in the DSi fluxes may be of significant importance for the silica cycle in the brackish estuary. However, considering the residence time of the water in the brackish estuary (70 days in summer, Soetaert and Herman 1995), the summer DSi uptake in the tidal river would not have affected the mouth of the estuary and the coastal zone before August of the same year. By late summer, blooms of diatoms and Phaeocystis sp. had terminated, DSi was no longer depleted and its concentration started to increase again in the coastal zone near the mouth of the estuary (Van der Zee and Chou 2005; Muylaert et al. 2006). As a result, the summer removal of DSi in the Scheldt tidal river is not expected to have had an important effect on the supply of DSi to the coastal zone during coastal phytoplankton blooms. Instead, the extent of the supply of DSi by the Scheldt to the coastal zone in spring seems to be principally supported by the winter riverine DSi flux, which is actually driven by the winter freshwater discharge because of constant winter riverine DSi concentrations.

Acknowledgments We are very grateful to Jean-Pierre Vanderborght for constructive discussions and comments on the manuscript. Claar van der Zee and Nathalie Roevros commented on previous versions of the manuscript. We would also like to thank Nathalie Roevros, Nicolas Canu, Renaat Dasseville, Christiane de Marneffe, Michaël Tsagaris and Stijn Vanneste for their assistance in field sampling and laboratory analyses. Victor Chepurnov isolated the Cyclotella sp. strains for the phytoplankton collection of the Ghent University. Data on water discharge were provided by the Ministry of the Flemish Community (Afdeling Maritieme Toegang). We would also like to thank the three anonymous reviewers for their constructive comments and suggestions. This study was financed by the Belgian Federal Science Policy Office (BELSPO) under contract number EV/11/17A (SISCO). Additional BELSPO funding from the TIMOTHY project (Interuniversity Attraction Pole, IAP, P6/13) is acknowledged. This is also a contribution to the EU IP CarboOcean (contract no. 511176-2). We would like to dedicate this paper to the late Roland Wollast who did the pioneering work on the silica biogeochemistry in the Scheldt estuary.

\section{References}

Abril G, Nogueira M, Etcheber H, Cabeçadas G, Lemaire E, Brogueira MJ (2002) Behaviour of organic carbon in nine contrasting European estuaries. Estuar Coast Shelf Sci 54:241-262

Admiraal W, Breugem P, Jacobs DMLHA, de Ruyter van Steveninck ED (1990) Fixation of dissolved silicate and sedimentation of biogenic silicate in the lower river Rhine during diatom blooms. Biogeochemistry 9:175-185

Alexandre A, Meunier J-D, Colin F, Koud J-M (1997) Plant impact on the biogeochemical cycle of silicon and related weathering processes. Geochim Cosmochim Acta 61(3):677-682

Anderson GF (1986) Silica, diatoms and a freshwater productivity maximum in Atlantic coastal plain estuaries, Chesapeake Bay. Estuar Coast Shelf Sci 22:183-197

Arndt S, Regnier P (2007) A model for the benthic-pelagic coupling of silica in estuarine ecosystems: sensitivity analysis and system scale simulation. Biogeosciences 4:331-352

Arndt S, Vanderborght J-P, Regnier P (2007) Diatom growth response to physical forcing in a macrotidal estuary: coupling hydrodynamics, sediment transport, and biogeochemistry. J Geophys Res 112:C05045

Bidle KD, Azam F (1999) Accelerated dissolution of diatom silica by marine bacterial assemblages. Nature 397:508512

Blecker SW, McCulley RL, Chadwick OA, Kelly EF (2006) Biologic cycling of silica across a grassland bioclimosequence. Glob Biogeochem Cycle 20:GB3023

Bouezmarni M, Wollast R (2005) Geochemical composition of sediments in the Scheldt estuary with emphasis on trace metals. Hydrobiologia 540(1-3):155-168

Carbonnel V (2009) Silica dynamics and retention in the Scheldt tidal river and estuary (Belgium/The Netherlands). Ph. D. thesis, Université Libre de Bruxelles, Belgium

Cary L, Alexandre A, Meunier J-D, Boeglin J-L, Braun J-J (2005) Contribution of phytoliths to the suspended load of biogenic silica in the Nyong basin rivers (Cameroon). Biogeochemistry 74:101-104

Chen MS, Wartel S, Van Eck B, Van Maldegem D (2005a) Suspended matter in the Scheldt estuary. Hydrobiologia 540(1-3):79-104

Chen MS, Wartel S, Temmerman S (2005b) Seasonal variation of floc characteristics on tidal flats, the Scheldt estuary. Hydrobiologia 540(1-3):181-195

Conley DJ (1997) Riverine contribution of biogenic silica to the oceanic silica budget. Limnol Oceanogr 42(4):774-777

Conley DJ (2002) Terrestrial ecosystems and the global biogeochemical silica cycle. Glob Biogeochem Cycle 16(4):68(1)-68(7)

Conley DJ, Schelske CL, Stoermer EF (1993) Modification of the biogeochemical cycle of silica with eutrophication. Mar Ecol Prog Ser 101:179-192

Conley DJ, Likens GE, Buso DC, Saccone L, Bailey SW, Johnson CE (2008) Deforestation causes increased dissolved silicate losses in the Hubbard Brook Experimental Forest. Glob Change Biol 14(11):2548-2554 
Cushing DH (1989) A difference in structure between ecosystems in strongly stratified waters and in those that are only weakly stratified. J Plankton Res 11(1):1-13

Dagnelie P (1973) Théorie et méthodes statistiques, vol 1. Presses agronomiques de Gembloux, Gembloux (In French)

Dagnelie P (2006) Statistique théorique et appliquée. Vol. 2, inférence statistique à une et à deux dimensions, $2^{\mathrm{e}}$ édition. Editions De Boeck Université, Bruxelles (In French)

Datnoff LE, Snyder GH, Korndorfer GH (eds) (2001) Silicon in agriculture. Studies in plant science 8 . Elsevier Science

De Sève MA (1993) Diatom bloom in the tidal freshwater zone of a turbid and shallow estuary, Rupert Bay (James Bay, Canada). Hydrobiologia 269/270:225-233

Delstanche S (2004) Contribution à l'étude du cycle biogéochimique de la silice dans le continuum aquatique de l'Escaut. MSc. thesis, Université Catholique de Louvain, Belgium (In French)

Derry LA, Kurtz AC, Ziegler K, Chadwick OA (2005) Biological control of terrestrial silica cycling and export fluxes to watersheds. Nature 433:728-731

Dougan WK, Wilson AL (1974) The absorptiometric determination of aluminium in water. A comparison of some chromogenic reagents and the development of an improved method. Analyst 99:413-430

Garnier J, d'Ayguesvives A, Billen G, Conley DJ, Sferratore A (2002) Silica dynamics in the hydrographic network of the Seine River. Océanis 28(3-4):487-508

Geider RJ (1987) Light and temperature dependence of the carbon to chlorophyll $a$ ratio in microalgae and cyanobacteria: implications for physiology and growth of phytoplankton. New Phytol 106:1-34

Hellings L, Dehairs F, Tackx M, Keppens E, Baeyens W (1999) Origin and fate of organic carbon in the freshwater part of the Scheldt Estuary as traced by stable carbon isotope composition. Biogeochemistry 47:167-186

Hildebrand M (2002) Lack of coupling between silicon and other elemental metabolisms in diatoms. J Phycol 38:841-843

Humborg C, Pastuszak M, Aigars J, Siegmund H, Mörth C-M, Ittekot V (2006) Decreased silica land-sea fluxes through damming in the Baltic Sea catchment-significance of particle trapping and hydrological alterations. Biogeochemistry 77:265-281

IRMB (Institut Royal Météorologique de Belgique) (20032004) Bulletins mensuels, Observations climatologiques, parties I et II. Institut Royal Météorologique de Belgique, Bruxelles (In French/Dutch)

Jacobs S, Struyf E, Maris T, Meire P (2008) Spatiotemporal aspects of silica buffering in restored tidal marshes. Estuar Coast Shelf Sci 80(1):42-52

Kamatani A, Oku O (2000) Measuring biogenic silica in marine sediments. Mar Chem 68(3):219-229

Koroleff F (1983) Determination of silicon. In: Grasshoff K, Ehrhardt M, Kremling K (eds) Methods of seawater analysis. Second, revised and extended edition. Verlag Chemie, Deerfield Beach, pp 174-187

Kronvang B, Bruhn AJ (1996) Choice of sampling strategy and estimation method for calculating nitrogen and phosphorus transport in small lowland streams. Hydrol Process 10:1483-1501
Lancelot C (1995) The mucilage phenomenon in the continental coastal waters of the North Sea. Sci Total Environ 165(1-3):83-102

Lionard M (2006) Spatio-temporal phytoplankton dynamics along the Scheldt-North Sea continuum based on HPLC/ CHEMTAX pigment analysis. Ph. D. thesis, Univ. of Ghent, Belgium

Lionard M, Muylaert K, Tackx M, Vyverman W (2008a) Evaluation of the performance of HPLC-CHEMTAX analysis for determining phytoplankton biomass and composition in a turbid estuary (Schelde, Belgium). Estuar Coast Shelf Sci 76(4):809-817

Lionard M, Muylaert K, Hanouti A, Maris T, Tackx M, Vyverman W (2008b) Inter-annual variability in phytoplankton summer blooms in the freshwater tidal reaches of the Schelde estuary (Belgium). Estuar Coast Shelf Sci 79(4):694-700

Loucaides S, Van Cappellen P, Behrends T (2008) Dissolution of biogenic silica from land to ocean: role of salinity and pH. Limnol Oceanogr 53(4):1614-1621

Mackey MD, Mackey DJ, Higgins HW, Wright SW (1996) CHEMTAX - a program for estimating class abundances from chemical markers: application to HPLC measurements of phytoplankton. Mar Ecol Prog Ser 144:265-283

Martin-Jézéquel V, Hildebrand M, Brzezinski MA (2000) Silicon metabolism in diatoms: implications for growth. J Phycol 36:821-840

McLusky DS (1993) Marine and estuarine gradients-an overview. Neth J Aquat Ecol 27(2-4):489-493

Meire P, Ysebaert T, Van Damme S, Van den Bergh E, Maris T, Struyf E (2005) The Scheldt estuary: a description of a changing ecosystem. Hydrobiologia 540(1-3):1-11

Moatar F, Meybeck M (2005) Compared performances of different algorithms for estimating annual nutrient loads discharged by the eutrophic River Loire. Hydrol Process 19:429-444

Moatar F, Meybeck M (2007) Riverine fluxes of pollutants: Towards predictions of uncertainties by flux duration indicators. C R Geosci 339:367-382

Moatar F, Person G, Meybeck M, Coynel A, Etcheber H, Crouzet P (2006) The influence of contrasting suspended particulate matter transport regimes on the bias and precision of flux estimates. Sci Total Environ 370:515-531

Muylaert K, Van Kerckvoorde A, Vyverman W, Sabbe K (1997) Structural characteristics of phytoplankton assemblages in tidal and non-tidal freshwater systems: a case study from the Schelde basin, Belgium. Freshw Biol 38:263-276

Muylaert K, Sabbe K, Vyverman W (2000) Spatial and temporal dynamics of phytoplankton communities in a freshwater tidal estuary (Schelde, Belgium). Estuar Coast Shelf Sci 50(5):673-687

Muylaert K, Van Wichelen J, Sabbe K, Vyverman W (2001) Effects of freshets on phytoplankton dynamics in a freshwater tidal estuary (Schelde, Belgium). Arch Hydrobiol 150(2):269-288

Muylaert K, Tackx M, Vyverman W (2005) Phytoplankton growth rates in the freshwater tidal reaches of the Schelde estuary (Belgium) estimated using a simple light-limited primary production model. Hydrobiologia 540(1-3):127-140 
Muylaert K, Gonzales R, Franck M, Lionard M, van der Zee C, Cattrijsse A, Sabbe K, Chou L, Vyverman W (2006) Spatial variation in phytoplankton dynamics in the Belgian coastal zone of the North Sea studied by microscopy, HPLC-CHEMTAX and underway fluorescence recordings. J Sea Res 55:253-265

Nelson DM, Tréguer P, Brzezinski MA, Leynaert A, Quéguiner B (1995) Production and dissolution of biogenic silica in the ocean: revised global estimates, comparison with regional data and relationship to biogenic sedimentation. Glob Biogeochem Cycle 9(3):359-372

Officer CB, Ryther JH (1980) The possible importance of silicon in marine eutrophication. Mar Ecol Prog Ser 3:83-91

Peterson DH, Smith RE, Hager SW, Harmon DD, Herndon RE, Schemel LE (1985) Interannual variability in dissolved inorganic nutrients in Northern San Francisco Bay Estuary. Hydrobiologia 129:37-58

Ploug H, Iversen MH, Koski M, Buitenhuis ET (2008) Production, oxygen respiration rates, and sinking velocity of copepod fecal pellets: direct measurements of ballasting by opal and calcite. Limnol Oceanogr 53(2):469-476

Ragueneau O, Tréguer P, Leynaert A, Anderson RF, Brzezinski MA, DeMaster DJ, Dugdale RC, Dymond J, Fischer G, Francois R, Heinze C, Maier-Reimer E, Martin-Jézéquel V, Nelson DM, Quéguiner B (2000) A review of the $\mathrm{Si}$ cycle in the modern ocean: recent progress and missing gaps in the application of biogenic opal as a paleoproductivity proxy. Glob Planet Change 26(4):317-365

Ragueneau O, Savoye N, Del Amo Y, Cotten J, Tardiveau B, Leynaert A (2005) A new method for the measurement of biogenic silica in suspended matter of coastal waters: using $\mathrm{Si}$ :Al ratios to correct for the mineral interference. Cont Shelf Res 25(5-6):697-710

Reynolds CS (1988) Potamoplankton: paradigms, paradoxes and prognoses. In: Round FE (ed) Algae and the aquatic environment. Biopress, Bristom, pp 285-311

Roubeix V, Becquevort S, Lancelot C (2008) Influence of bacteria and salinity on diatom biogenic silica dissolution in estuarine systems. Biogeochemistry 88(1):47-62

Schuchardt B, Schirmer M (1991) Phytoplankton maxima in the tidal freshwater reaches of two coastal plain estuaries. Estuar Coast Shelf Sci 32:187-206

Schuchardt B, Haesloop U, Schirmer M (1993) The tidal freshwater reach of the Weser Estuary: riverine or estuarine? Neth J Aquat Ecol 27(2-4):215-226

Sicko-Goad LM, Schelske CL, Stoermer EF (1984) Estimation of intracellular carbon and silica content of diatoms from natural assemblages using morphometric techniques. Limnol Oceanogr 29(6):1170-1178

Soetaert K, Herman PMJ (1995) Estimating estuarine residence times in the Westerschelde (The Netherlands) using a box model with fixed dispersion coefficients. Hydrobiologia 311:215-224

Soetaert K, Hoffmann M, Meire P, Starink M, van Oevelen D, Van Regenmortel S, Cox T (2004) Modeling growth and carbon allocation in two reed beds (Phragmites australis) in the Scheldt estuary. Aquat Bot 79:211-234

Soetaert K, Middelburg JJ, Heip C, Meire P, Van Damme S, Maris T (2006) Long-term change in dissolved inorganic nutrients in the heterotrophic Scheldt estuary (Belgium, The Netherlands). Limnol Oceanogr 51(1, part 2):409-423
Struyf E, Van Damme S, Meire P (2004) Possible effects of climate change on estuarine nutrient fluxes: a case study in the highly nutrified Schelde estuary (Belgium, The Netherlands). Estuar Coast Shelf Sci 60(4):649-661

Struyf E, Van Damme S, Gribsholt B, Middelburg JJ, Meire P (2005) Biogenic silica in tidal freshwater marsh sediments and vegetation (Schelde estuary, Belgium). Mar Ecol Prog Ser 303:51-60

Struyf E, Dausse A, Van Damme S, Bal K, Gribsholt B, Boschker HTS, Middelburg JJ, Meire P (2006) Tidal marshes and biogenic silica recycling at the land-sea interface. Limnol Oceanogr 51(2):836-846

Struyf E, Van Damme S, Gribsholt B, Bal K, Beauchard O, Middelburg JJ, Meire P (2007a) Phragmites australis and silica cycling in tidal wetlands. Aquat Bot 87:134-140

Struyf E, Temmerman S, Meire P (2007b) Dynamics of biogenic $\mathrm{Si}$ in freshwater tidal marshes: $\mathrm{Si}$ regeneration and retention in marsh sediments (Scheldt estuary). Biogeochemistry 82:41-53

Suzumura M, Kokubun H, Arata N (2004) Distribution and characteristics of suspended particulate matter in a heavily eutrophic estuary, Tokyo Bay, Japan. Mar Pollut Bull 49:496-503

Temmerman S, Govers G, Wartel S, Meire P (2003) Spatial and temporal factors controlling short-term sedimentation in a salt and freshwater tidal marsh, Scheldt estuary, Belgium, SW Netherlands. Earth Surf Process Landf 28:739-755

Tréguer P, Pondaven P (2000) Silica control of carbon dioxide. Nature 406:358-359

Tréguer P, Nelson DM, Van Bennekom AJ, DeMaster DJ, Leynaert A, Quéguiner B (1995) The silica balance in the world ocean: a reestimate. Science 268:375-379

Turner RE, Qureshi N, Rabalais NN, Dortch Q, Justic' D, Shaw RF, Cope J (1998) Fluctuating silicate:nitrate ratios and coastal plankton food webs. Proc Natl Acad Sci USA 95:13048-13051

Van Cappellen P, Dixit S, van Beusekom J (2002) Biogenic silica dissolution in the oceans: reconciling experimental and field-based dissolution rates. Glob Biogeochem Cycle 16(4): 1075

Van Damme S, Struyf E, Maris T, Ysebaert T, Dehairs F, Tackx M, Heip C, Meire P (2005) Spatial and temporal patterns of water quality along the estuarine salinity gradient of the Scheldt estuary (Belgium and The Netherlands): results of an integrated monitoring approach. Hydrobiologia 540(1-3):29-45

Van der Zee C, Chou L (2005) Seasonal cycling of phosphorus in the Southern Bight of the North Sea. Biogeosciences 2:27-42

Van der Zee C, Roevros N, Chou L (2007) Phosphorus speciation, transformation and retention in the Scheldt estuary (Belgium/The Netherlands) from the freshwater tidal limits to the North Sea. Mar Chem 106(1-2):76-91

Verbanck M, Vanderborght J-P, Wollast R (1994) Major ion content of urban wastewater: assessment of per capita loading. Res J Water Pollut Control Federation 61(11/ 12):1722-1728

WLHO (Waterbouwkundig Laboratorium en Hydrologisch Onderzoek) (1966) Stormvloeden op de Schelde, parts 3 and 4. Borgerhout, Antwerp (In Dutch) 
Wollast R (1974) The silica problem. In: Goldberg ED (ed) The sea, vol 5. Wiley, New York, pp 359-392

Wright SW, Jeffrey SW (1997) High-resolution HPLC system for chlorophylls and carotenoids of marine phytoplankton.
In: Jeffrey SW, Mantoura RFC, Wright SW (eds) Phytoplankton pigments in oceanography: guidelines to modern methods. UNESCO Publishing, Paris, pp 327-341 